Chapter 10

\title{
Soil Organic Matter Stability as Affected by Land Management in Steppe Ecosystems
}

\author{
Elmira Saljnikov, Dragan Cakmak and \\ Saule Rahimgalieva \\ Additional information is available at the end of the chapter \\ http://dx.doi.org/10.5772/53557
}

\section{Introduction}

\subsection{Soil organic matter status}

Soil organic matter (SOM) is most reactive and powerful factor in the formation of soil and in its fertility. Formation of soil and accumulation of organic matter are a function of interactions between biological factors and parent rocks under certain hydrothermal conditions and are one of the sections of a continuous chain of the trophic bounds between different life forms, serving as a first and a last section at the same time. The later is because SOM contain the main nitrogen stock, nearly the half of phosphorus, significant part of sulphur and other macro- and micronutrients for sustaining life and productivity of plants. Although soil organic matter comprise only five percent of total soil structure it has been a major research topic throughout the history of soil science, which is generally regarded to have been ongoing for approximately a century $[1,2]$.

Discovering the role and fate of soil organic matter has been a great challenge for the scientists. There are many argues about definitions of SOM among soil scientist. One of the most dynamic definitions of the SOM was given by [3]: the amount of organic carbon contained in a particular soil is a function of the balance between the rate of deposition of plant residues in or on soil and the rate of mineralization of the residue carbon by soil biota. In fact organic matter in soil always is in a very dynamic state, where transformations of bio-products occur constantly. The mechanisms through which soil organic $\mathrm{C}$ can be biologically stabilized depend on the decomposition of the soil mineral phase and the chemical structure of the organic residues added to the soil. 
Climate is the most powerful factor that determines the array of plant species at any given location, the quantity of plant material produced, and the intensity of microbial activity in the soil. Climate influences soil organic carbon (SOC) content primarily through the effects of temperature, moisture, and solar radiation. Related studies found that amounts of SOC were positively correlated with precipitation and, at a given level of precipitation, negatively correlated with temperature [4,5]. Climatic influences on biologically active fractions of SOM are not well understood. Therefore, one of the focuses in this study was investigation of the dynamics of labile SOM under the different hydrothermal conditions of steppe ecosystems.

Another powerful factor determining SOM reserves is plant biomass inputs and outputs. In agricultural systems, where soil and plant residues are often intensively manipulated, human impact on decomposition is especially pronounced [6]. Management practices like tillage, selection of crops and cropping sequences, and fertilization can alter decomposition rates by their effects on soil moisture, soil temperature, aeration, composition and placement of residues. Many studies confirm that under the similar climatic condition, carbon and nitrogen retention in soil is influenced by crop management systems, such as crop rotation [7, 8], tillage [5, 9], residue management [10] and fertilization and fertility [7, 10, 11]. This Chapter will discuss an impact of different land management practices on the labile (biologically active) pool of soil organic matter.

\subsection{Decomposition}

Decomposition is the progressive break down of organic, ultimately into inorganic constituents. The decomposition process is mediated mainly by soil microorganisms, which derive energy and nutrients from decomposing substrate. Plant litter decomposes very rapidly and although the carbon from plant litter represents only a small fraction of $\mathrm{C}$ in soil, about half of the $\mathrm{CO}_{2}$ output from soil, globally, comes from decomposition of the annual litter fall [12]. Decomposition is central to the biogeochemical cycles in terrestrial, aquatic and atmospheric systems. It releases nutrients and energy associated in organic materials and feeds them back into local and global cycles, thereby affecting land, and air and water quality (Fig. 1).

Three interrelated factors regulate decomposition: the quality of the residue, the physicalchemical environment in which decomposition occurs and the type of organisms in the decomposer community. All organic carbon in soils can serve as potentially suitable as substrate. Vegetation can influence SOC levels as a result of the amount, placement and biodegradability of plant residues returned to the soil. The fate of surface deposited residues depends on the activity of soil microorganisms and fauna and their ability to mix these residues into surface mineral horizons. Microorganisms are the major contributors to soil respiration and are responsible for $80-95 \%$ of the mineralization of carbon. Humans can affect decomposition by altering some of these factors, especially in agricultural systems. The current understanding of decomposition processes, learned from field and laboratory studies, is embodied in simulation models, e.g., the first-order kinetic model [110].

One of the effects of global warming is accelerated decomposition of soil organic matter, thereby releasing $\mathrm{CO}_{2}$ to the atmosphere, which will further enhance the warming trend 
[104]. The United Nations Framework Convention on Climate change (Kyoto Protocol of 1997), allows organic carbon stored in arable soils to be included in calculations of net carbon emissions. By altering organic matter production, litter quality, and belowground $\mathrm{C}$ allocation, however, changes in vegetation type can influence microbial decomposition [105] and root respiration and therefore soil respiration rates [80]. As a result of global climate change and alterations in land use many ecosystems are currently experiencing concurrent changes in the abiotic and biotic controls on soil respiration. Given the large quantity of $\mathrm{CO}_{2}$ that soils respire annually and the role $\mathrm{CO}_{2}$ plays in greenhouse warming, an understanding of SR response to climate change and alterations in vegetation resulting from land use is critical.

\subsection{Labile pool of soil organic matter}

Labile carbon is the fraction of soil organic carbon with most rapid turnover times and its oxidation drives the flux of $\mathrm{CO}_{2}$ between soils and atmosphere. Labile organic matter pools are fine indicators of soil quality that influence soil function in specific ways and that are much more sensitive to changes in soil management practice [e.g., 13]. The biggest and main source for labile organic matter is a 'light' fraction organic matter (or particulate $\mathrm{OM}$, or macroorganic matter; [8, 14-17] that consists of partially decomposed plant litter. This 'light' organic matter acts as a substrate for soil microbial activity, a short-term reservoir of nutrients, a food source for soil fauna and loci for formation of water stable macroaggregates.

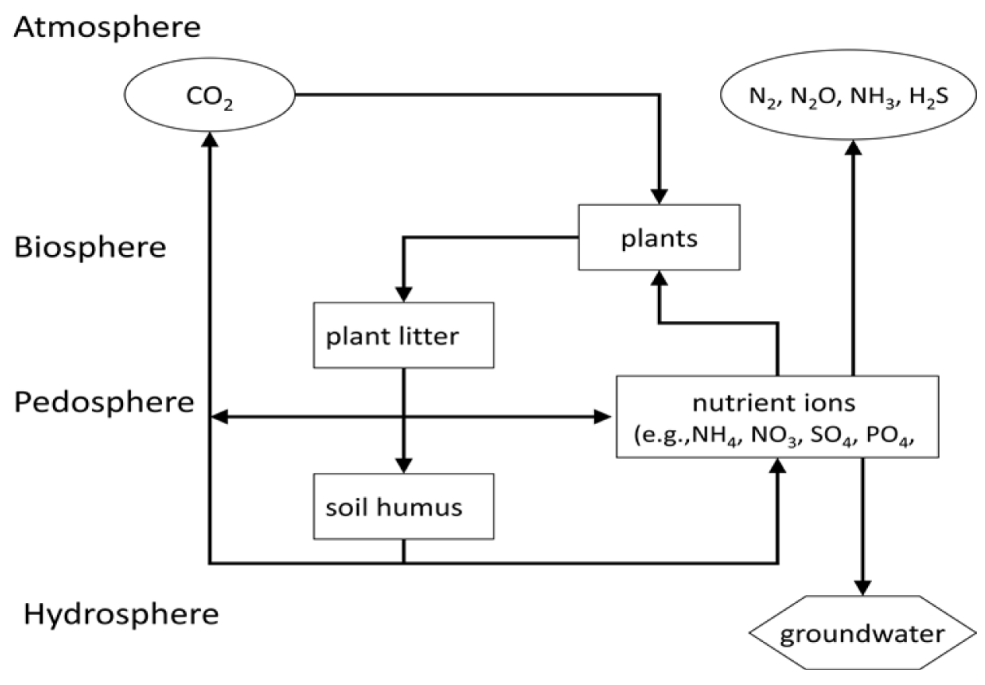

Figure 1. Conceptual model of soil organic matter decomposition (modified from [106]) 


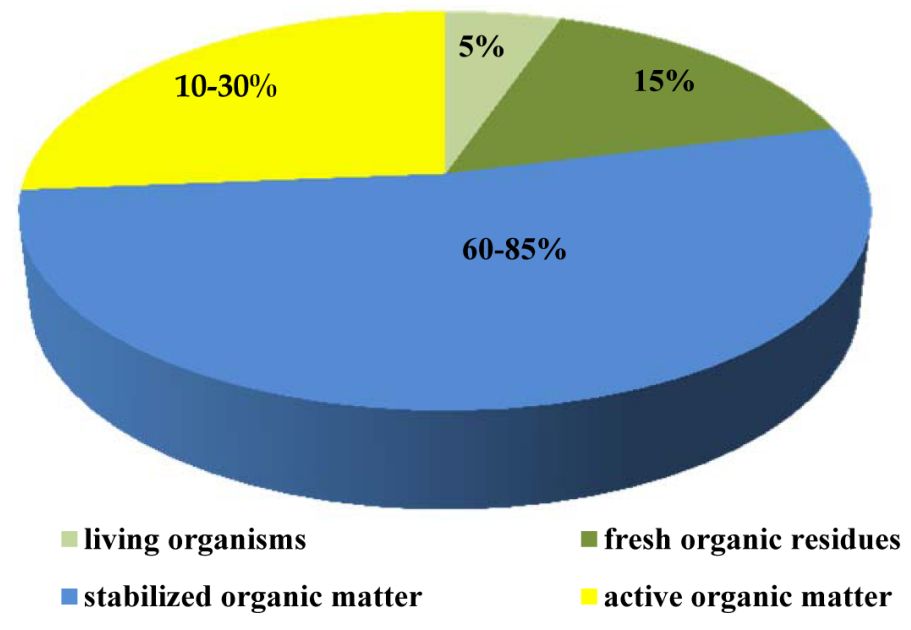

Figure 2. Composition and distribution of fractions of soil organic matter

The biological determination of labile SOM is the carbon decomposed by microorganisms during the microbial growth. This biological definition of labile SOM includes two aspects: labile soil organic carbon chemically and physically assessable; the organic carbon that is chemically decomposable but physically un-assessable due to protection by clay minerals is not considered as a labile organic carbon. Generally, soil organic matter is divided into stable (70-96\%), active (2-30\%) and plant litter (0-20\%) fractions (Fig.2). The active fraction mainly consists of microbial biomass and their metabolites, the organic substrate in different stages of decomposition and non-humic substances, with turnover time from 0.8 to 5 years. The stabilized or passive fraction of SOM is passive, chemically and physically protected matters. The physically protected OM has turnover time from 20 to 50 years; the chemically protected -from 800 to 1200 years.

The 10 to $30 \%$ active fraction is responsible for the support of soil microorganisms. This fraction is most sensitive to soil management practices. Although labile OM comprises a small part of total SOM, it is the main source for nutrients and energy for microorganisms and plants, and main source for carbon dioxide flux from soil. The roles of stable and labile SOM differ. An active fraction mainly influences the activity of microorganisms, the stability of macroaggregates, filtration speed, and the speed of nutrient mineralization. Whilst, the stable fraction influences mainly water-holding capacity, soil cation exchangeable capacity and soil microaggregation.

Fresh plant litter decomposes very quickly and the decomposition usually occurs not as a single step, but as a cascade. Fresh material, usually plant residue, undergo hydrolysis and redox reactions and then converted into altered forms. The transformed organic material, so called 'light' fraction (LF), in turn, is susceptible to further decomposition. A small part of LF is utilized for microbial synthesis, which after death contribute back to LF. Greatest part of LF is subjected to further mineralization resulting in mineral products, which is of direct 
practical interest of soil scientists from agronomical and ecological point of view, because as mentioned above, about half of the $\mathrm{CO}_{2}$ output from soil, globally, comes from decomposition of the annual litter fall.

Thus, transformations of SOM are generally concentrated within labile pool. The end products of organic matter mineralization (e.g., $\mathrm{CO}_{2}, \mathrm{NO}_{3}, \mathrm{NH}_{4}$ ) can give us valuable information about ability of a given soil to supply plants with nutrients and/or ability to stabilize soil organic matter.

Nitrogen $(\mathrm{N})$ is generally the most common growth-limiting nutrient in agricultural production systems Nitrogen taken up by crops is derived from a number of sources, particularly from fertilizer, biological $\mathrm{N}$ fixation and mineralization of $\mathrm{N}$ from soil organic matter, crop residues, and manures [18]. Large amounts of mineralizable $\mathrm{N}$ can accumulate under grassland with the result that crops grown immediately after cultivation of long-term grass may derive much of their $\mathrm{N}$ from mineralization. In contrast, soils that have been intensively cropped often mineralize little $\mathrm{N}$, leaving crops heavily dependent on fertilizer nitrogen. This chapter will present the impact of different fertilization experiments on soil labile OM.

Labile fractions of SOM neither have been fully described nor successfully isolated [19, 20]. However, procedurally defined fractions such as carbon and nitrogen mineralized under controlled conditions and "light" fraction organic carbon proved to be good indicators of subtle changes in SOM, because they affects the nutrient dynamics within single growing season, the organic matter content under contrasting management regimes, and $\mathrm{C}$ sequestration over extended periods of time. Organic matter quality may also be characterized by estimates of kinetically defined pools obtained by fitting the simulation models to data of carbon and nitrogen mineralization [21,22]. Although soil labile organic carbon is constituted of amino acids, simple carbohydrates, a fraction of microbial biomass, and other simple organic compounds, a clear chemical or physical definition of soil labile organic carbon is difficult if not impossible. We here present a biological definition of soil labile organic carbon as microbial degradable carbon associated with microbial growth. This biological definition includes two aspects: soil labile organic carbon is both chemically degradable and physically accessible by soil microbes. Organic carbon that is chemically degradable but physically inaccessible by microbes due to clay mineral protection is not regarded here as soil labile organic carbon [13].

Mollisols soils are the most fertile and productive soils and therefore they are often overexploited for agricultural needs. The area under Mollisols in Kazakhstan occupies 25.3 million ha and in Ukraine 60.4 million ha. During the Soviet period the political aim was a rapid increase in grain production that was achieved by indiscriminate plowing of as large area of virgin lands as possible. However, such intensive cultivation of these soils resulted in drastic decrease in its humus content. In this Chapter four types of Mollisols: Hupludolls, Argiudolls, Calciustolls and Haplustolls studied for characterization of the "light fraction organic matter" for the scenarios considered and estimation of relationship between $\mathrm{C} / \mathrm{N}$ ratio and mineralization rates are presented. 


\section{Materials and methods}

\subsection{Description of study sites}

Four experimental sites from Eurasian steppes were examined for soil organic matter fraction. They are: Kharkov (dry forest-steppe, east Ukraine), Uman (moist forest-steppe, central Ukraine), Kherson (dry steppe, south Ukraine) and Astana (dry steppe, northern Kazakhstan,). The sites are located in different soil-ecological zones and differ in the amount of precipitation, temperature, soil type and vegetation

\subsection{Soil sampling and analysis.}

Topsoil samples (0-20-cm) were collected in spring-summer. Three sub-samples for chemical and five sub-samples for biological analysis were taken from each sampling point. The soil samples were air-dried followed by grinding, and were passed through a 2 -mm sieve for chemical analysis. Samples for biological analysis were stored at fresh condition at $4^{\circ} \mathrm{C}$ before analysis. The dried soil samples were analyzed for total $\mathrm{N}$ concentration using a full automatic analyzer (Shimazu NC-800-13N). Organic C was determined by dichromate oxidation method [23].

\subsection{Labile carbon (Potentially Mineralizable Carbon, PMC)}

The rate of disappearance of plant residues can be described using a kinetic model. Firstorder kinetic model is usually used to characterize decomposition of plant residues, assuming that the annual input of plant residues is independent of the rate of their decomposition. Using first-order kinetics to describe decomposition implies that the metabolic potential of the soil microbial biomass exceeds the substrate supply.

Carbon mineralization was determined using laboratory incubation techniques via measuring soil respiration. The fresh soils were brought to $50 \%$ of WHC followed by incubation in a square-plastic jar $(500-\mathrm{ml})$ at $30^{\circ} \mathrm{C}$ for 70 days. The evolved $\mathrm{CO}_{2}$ was trapped in an alkali solution (10-ml of $1 \mathrm{M} \mathrm{NaOH})$ that was replaced every 14 days, and cumulative $\mathrm{CO}_{2}$ was measured by titration with $0.5 \mathrm{MHCl}$. The amount of mineralizable carbon was estimated from the rate of $\mathrm{CO}_{2}-\mathrm{C}$ evolved during 70 days of incubation using nonlinear regression according to the following equation [24]: $\mathrm{Cmin}=\mathrm{C}_{0}\left(1-\mathrm{e}^{-k t}\right)$, where, $C$ min is an experimental value of mineralized $C\left(\mathrm{mg} \mathrm{kg}^{-1}\right.$ soil) at time $t$ (days) that was plotted to fit the equation, $C_{0}$ is potentially mineralizable carbon (PMC) ( $\mathrm{mg} \mathrm{kg}^{-1}$ soil) that was calculated after fitting the curve, and $k$ is a nonlinear mineralization constant, i.e. the fraction mineralized per day $\left(\mathrm{d}^{-1}\right)$ [25].

\subsection{Labile nitrogen (Potentially Mineralizable Nitrogen, PMN)}

Potentially mineralizable $\mathrm{N}$ is a measure of the active fraction of soil organic $\mathrm{N}$, which is chiefly responsible for the release of mineral $\mathrm{N}$ through microbial action. Mineralizable $\mathrm{N}$ is composed of a heterogeneous array of organic substrates including microbial biomass, residues of recent crops, and humus. Despite a continuing research effort [26, 27], chemical tests 
that are selective for the mineralizable portion of soil $\mathrm{N}$ are not available and incubation assays remain the preferred way of estimating mineralizable $\mathrm{N}$.

Mineralized N was determined after incubation of soils for 2-, 4-, 6-, 8-, 10-weeks and analyzed for nitrate and ammonium $\mathrm{N}$ content by colorimetric method following extraction with $2 \mathrm{NKCl}$ solution. Nitrate $\mathrm{N}$ was analyzed after reduction of $\mathrm{NO}_{3}$ ions to $\mathrm{NO}_{2}$ by passing the extraction through cadmium column. Ammonium $\mathrm{N}$ was analyzed by salicylate nitroprusside method [18]. The amount of mineralizable $\mathrm{N}\left(\mathrm{N}_{0}\right)$ was obtained after fitting the data of mineralized $\mathrm{N}$ (Nmin) every 14 days to the first order kinetic model [25 ]: $\mathrm{Nmin}=\mathrm{N}_{0}^{*}(1-$

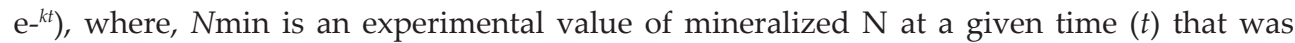
plotted to fit the equation, $N_{0}$ is a potentially mineralizable nitrogen (PMN) that was calculated after fitting the curve, and $k$ is nonlinear mineralization constant.

\subsection{Microbial biomass}

Soil microbial biomass measurements have been used in studies of soil organic matter dynamics and nutrient cycling in a variety of terrestrial ecosystems. They provide a measure of the quantity of living microbial biomass present in the soil, and in arable soils account for $\sim 1 \%-5 \%$ of the total soil organic matter $[28,29]$. Measurements of the carbon (C) and nitrogen $(\mathrm{N})$ contained in the soil microbial biomass provide a basis for studies of the formation and turnover of soil organic matter, as the microbial biomass is one of the key definable fractions [30]. The data can be used for assessing changes in soil organic matter caused by soil management [31] and tillage practices [32], for assessing the impact of management on soil strength and porosity, soil structure and aggregate stability [33], and for assessing soil $\mathrm{N}$ fertility status [21].

Soil microbial biomass was determined by chloroform fumigation-extraction technique as described by [34]. For each sample, four sub-samples of field-moist soil were placed in flasks, moistened to field capacity and conditioned for 3 days at $25^{\circ} \mathrm{C}$. Two sub-samples were fumigated with chloroform in a vacuum chamber for 5 days at $25^{\circ} \mathrm{C}$ and the other two sub-samples (controls) were incubated without fumigation at the same temperature. All samples were extracted with $0.5 \mathrm{~m}$ of $\mathrm{K}_{2} \mathrm{SO}_{4}$ at ratio 5:1. Microbial biomass $\mathrm{C}$ was measured by dissolved organic carbon analyzer (TOC-5000) and microbial biomass $\mathrm{N}$ was determined by colorimetric method. The microbial biomass $\mathrm{C}$ and $\mathrm{N}$ were calculated using an equation relating the increased release of $\mathrm{C}$ and $\mathrm{N}$ as a result of $\mathrm{CHCl}_{3}$ fumigation and a factor representing the fraction of biomass $\mathrm{C}$ and $\mathrm{N}$ extracted by $\mathrm{K}_{2} \mathrm{SO}_{4}[35]$.

\section{6. “Light" fraction organic matter (LF)}

"Light" fraction organic matter (LFOM) was separated by density separation using reagentgrade NaI solution adjusted to $1.8 \mathrm{~g} \mathrm{~cm}^{-3}$ [36]. $10 \mathrm{~g}$ of soil was suspended in $40 \mathrm{ml}$ of NaI solution (sp.gr. $=1,7$ ) and the soil dispersed for 30 seconds using a Virtis homogenizer. After centrifugation, the floating material, i.e., the 'light' fraction was transferred directly to a vacuum filtration unit. The LFOM was then washed (three aliquots of $10 \mathrm{ml} 0.01 \mathrm{M} \mathrm{CaCl}_{2}$ followed by three aliquots of distilled water), dried at $70^{\circ} \mathrm{C}$ for $15 \mathrm{~h}$ and weighed. The residue 
was re-suspended and the procedure was repeated to ensure complete collection of the LF. The composite LF was finely ground and analyzed for $\mathrm{N}$ and C concentrations.

\subsection{Statistics}

Descriptive statistical analyses were performed using SYSTAT-8 software [24]. Variability among treatments in each region was within the range of variability among the regions for all the cases. Sigma Plot 8 software [25] was applied for modeling $C$ mineralization pattern and mineralization rate constant.

\section{Impact of soil management practices on content of total organic $\mathrm{C}$ and $\mathbf{N}$ in soil}

\subsection{Soil total $\mathrm{C}$ and $\mathrm{N}$ in fertilization experiment}

Mean annual mineralization of humus depends upon many factors. However, in case of unified soil and climatic conditions the limiting factor of soil organic matter mineralization becomes the cultivated plant and the technology of crop cultivation. Time, depth, frequency and intensity of cultivation are directly related to the amount of humus mineralization $[37,38]$.

The experiment with application of different dozes of mineral and organic fertilizers was conducted on Mollisols, in Uman (Table 1). The results of the study confirm the role of manure in contribution to both stable and labile soil organic matter. The content of soil organic carbon was not increased after 36 years application of mineral fertilizer in most of the treatments, compared to the control, while application of high rates of manure $(\mathrm{O})$ alone maintained the higher accumulation of soil organic carbon (Table 2).

Manure contains humic acids [39], which directly contributes to the soil humic acids and favors humification processes [40,41]. As this experiment has been performing since 1964, the long-term input of high rates of manure contributed to SOM via direct inputs of humic acids into the soil, showing the higher soil organic $\mathrm{C}$ than in other treatments. Content of total $\mathrm{N}$ in the treatments was not statistically different as indicated by the same letters in Table 2 . Insignificant effect of the mineral fertilizers on the accumulation of soil organic $\mathrm{C}$ and $\mathrm{N}$ is due to quick depletion of mineral fertilizer in the soil either by means of microbial utilization [42] and by plant consumption, or by direct losses via leaching and/or volatilization

\subsubsection{Soil total $C$ and $N$ in fallow frequency experiment in Astana, Kazakhstan}

Under nearly 50 years of monoculture of wheat, summer bare fallow has been practiced in crop rotation in order to retain moisture, to accumulate nutrients through mineralization and to control weed infestation. Fallowed fields are usually cultivated many times to keep the land bare during the whole cropping season. Of great concern is, however, the adverse effect of fallow, that is, the changes in soil organic matter (SOM) quality and quantity in the 
context of degradation of the fertility of chernozem soils and subsequent agricultural sustainability. The studies of [43-45] have demonstrated that fallowing significantly exacerbates the depletion of SOM. Organic C and N content of soil after 33 years of cropping decreased with increasing frequency of fallow in a rotation on Canadian soils (53).

\begin{tabular}{|c|c|c|c|c|}
\hline \multirow{2}{*}{$\begin{array}{l}\text { Treatments } \\
\text { CON }\end{array}$} & \multirow{2}{*}{$\begin{array}{l}\begin{array}{c}\text { Fertilization rates } \\
\text { kg ha }^{-1} \mathbf{N}_{\text {year }}^{-1}\end{array} \\
\text { no }\end{array}$} & \multirow{2}{*}{$\begin{array}{c}\text { Fertilizer } \\
\text { no }\end{array}$} & \multicolumn{2}{|c|}{$\begin{array}{l}\mathrm{N} \text { applied per rotation } \\
\text { (10 years), } \mathrm{kg} \mathrm{N} \mathrm{ha-1}^{-1} \text { rotation }\end{array}$} \\
\hline & & & no & no \\
\hline M1 & $\mathrm{N}_{45}$ & $\left(\mathrm{NH}_{4}\right)_{2} \mathrm{SO}_{4}$ & 450 & 450 \\
\hline M3 & $N_{135}$ & $\left(\mathrm{NH}_{4}\right)_{2} \mathrm{SO}_{4}$ & 1350 & 1350 \\
\hline $\mathrm{O}$ & Manure $\mathrm{N}_{67.5}$ & manure & 675 & 675 \\
\hline \multirow[t]{2}{*}{ MO1 } & $\mathrm{N}_{22}+$ manure $\mathrm{N}_{22.5}$ & $\left(\mathrm{NH}_{4}\right)_{2} \mathrm{SO}_{4}$ & 225 & 450 \\
\hline & & manure & 225 & \\
\hline \multirow[t]{2}{*}{$\mathrm{MO3}$} & $\mathrm{N}_{45}$ & $\left(\mathrm{NH}_{4}\right)_{2} \mathrm{SO}_{4}$ & 675 & 1350 \\
\hline & & manure & 675 & \\
\hline
\end{tabular}

*Amount of $\mathrm{N}$ in manure was calculated as: one ton of cattle manure contains approximately $5 \mathrm{~kg}$ of $\mathrm{N}$

Table 1. Fertilization treatments in Uman experimental site from 10-year crop rotation in surface soil of Argiudolls, Ukraine

\begin{tabular}{|c|c|c|c|c|}
\hline $\begin{array}{l}\text { Fertilization rates } \\
\qquad{\text { kg ha-1 } \text { year }^{-1}}\end{array}$ & Treatments & \multicolumn{2}{|c|}{$\mathrm{g} \mathrm{kg}^{-1}$ soil } & $\mathrm{C} / \mathrm{N}$ ratio \\
\hline no & CON & $20.4 a$ & $1.64 a$ & 12 \\
\hline $\mathrm{N}_{45}$ & M1 & $19.6 a$ & $1.62 \mathrm{a}$ & 12 \\
\hline $\mathrm{N}_{135}$ & M3 & $20.8 a$ & $1.76 a$ & 12 \\
\hline Manure $\mathrm{N}_{67.5}$ & $\mathrm{O}$ & $21.9 b$ & $1.77 a$ & 12 \\
\hline $\mathrm{N}_{22}+$ manure $\mathrm{N}_{22.5}$ & MO1 & $20.4 a$ & $1.71 \mathrm{a}$ & 12 \\
\hline $\mathrm{N}_{22}+$ manure $\mathrm{N}_{67.5}$ & MO3 & $20.1 a$ & $1.72 \mathrm{a}$ & 12 \\
\hline
\end{tabular}

Table 2. Effect of fertilization treatments on soil organic C (SOC) and total N (TN) in surface soil of Argiudolls, Uman, Ukraine

The objectives of this study were to examine the effects of summer fallow on the characteristics of SOM on a long-term basis (length of crop rotation with a variety of frequencies of fallow) as well as on a short-term basis (pre- and post-fallow phases) with special reference to readily decomposable fractions.

To investigate the impact of bare fallow on soil SOM dynamics the five representatives fallow-spring wheat crop rotation were selected (2-year, 4-year and 6-year with one year of 
bare fallowing). Soil samples were collected from pre- (2R-pre, 4R-pre and 6R-pre) and postfallow (2R-post, 4R-post and 6R-post) phases in each rotation. Also, for comparison the continuous cropping of spring wheat $(\mathrm{CW})$ and continuous fallowing $(\mathrm{CF})$ were sampled for comparison.

Soil organic carbon (SOC) content was significantly affected by long-term fallowing. The CF system maintained the least SOC, while 6R and CW stored the most SOC (Table 3). SOC was inversely proportional to fallow frequency, indicating the negative effect of fallow on longterm accumulation of SOM. The effect of the rotations on total nitrogen (TN) paralleled that described for SOC. The highest TN concentrations were observed in the $6 \mathrm{R}$ and CW systems and lowest concentrations in the CF system.

To protect the field against weeds and to store more moisture and nutrients in the soil, fallowed field are cultivated 4 to 5 times during the vegetative season. Such intensive mechanical disturbance causes enhanced mineralization of SOM in fallow, firstly, due to better aeration of surface soil, and secondly, particular organic matter occluded within aggregates might become exposed to microbial attack after disruption of aggregates. Additionally, bare fallow does not contribute plant residues for the replenishment of SOM.

In general, distributions of SOC and TN among rotations with different fallow frequencies were comparable to those reported by [50-52] for Chernozem soils. Frequently fallowing systems such as $2 \mathrm{R}$ showed less SOM than less frequently fallowing systems, such as $6 \mathrm{R}$. Our results confirmed the findings from North American arable systems that frequently fallowing system accelerates mineralization of SOM [51-53]

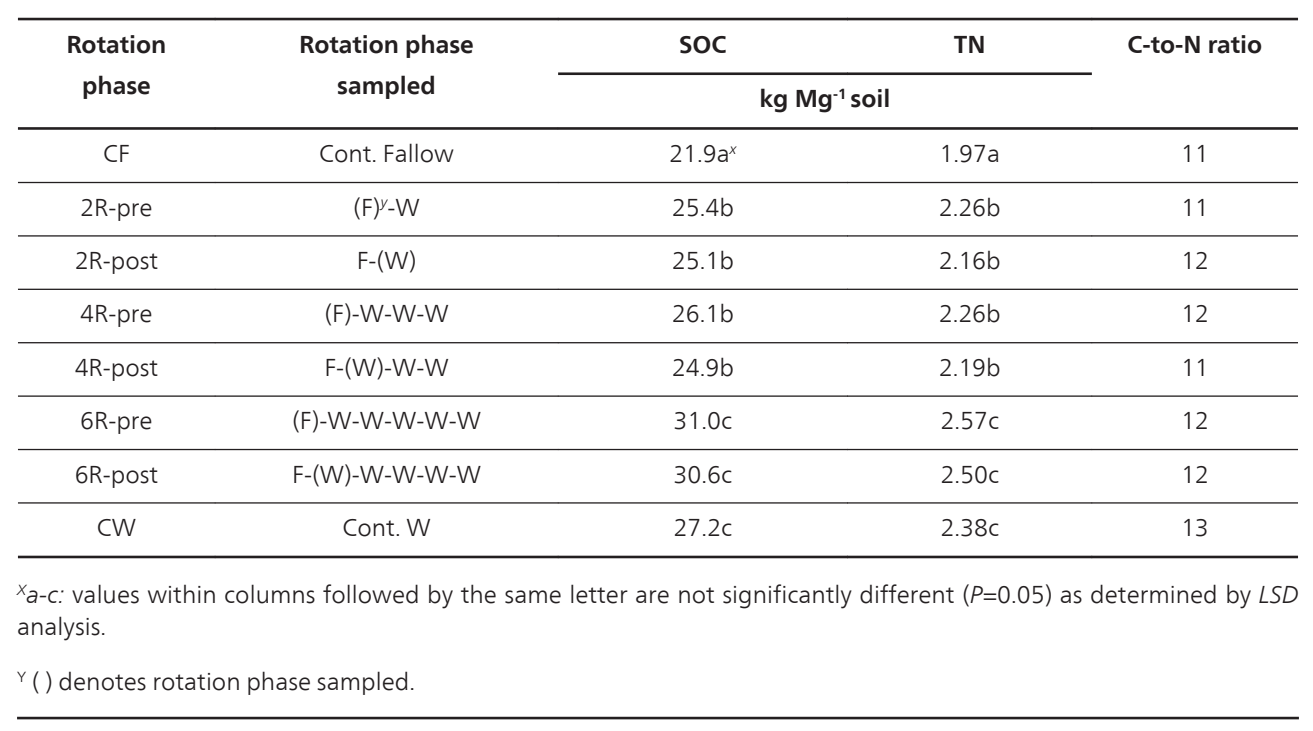

Table 3. Effects of fallow (F) frequency and rotation phase on soil organic C (SOC) and total N (TN) in surface soil of Haplustolls, Astana, Kazakhstan 


\section{Impact of agricultural practices on labile SOM}

Labile SOM fractions such as the "light" fraction C [14],microbial biomass carbon [15], mineralizable $C[8,16]$ are highly sensitive tochanges in $C$ inputs to the soil and will provide a measurable change before any such change in total organic matter [17].In contrast, the more stable (humified) poolsare probably the more appropriate and representative fractions for $\mathrm{C}$ sequestration characterization [54].

Carbon mineralization potentials measured via soil respiration in a cascade measurement of the carbon dioxide efflux produced from soil metabolic processes consists of mainly microbial decomposition of soil organic matter and root respiration [55]. A great deal of research money and effort has been invested in studies of soil respiration in recent years because of the potential impacts of this process on the Greenhouse Effect [55]. Measurement of potentially mineralizable $\mathrm{C}$ represents a bioassay of labile organic matter using the indigenous microbial community to release labile organic fractions of C. Mineralizable $\mathrm{N}$ is also an important indicator of the capacity of the soil to supply $\mathrm{N}$ for crops. Individual labile organic matter fractions, such as easily mineralizable carbon and nitrogen, the microbial biomass and activity, are sensitive to changes in soil management and have specific effects on soil function [8]. Together they reflect the diverse but central effects that organic matter has on soil properties and processes.

\subsection{Soil labile OM in fertilization and experiment}

In the $21^{\text {st }}$ century the mineral fertilizers became determinant for obtaining contented yield of agricultural crops. However, the application of only mineral fertilizer might lead to accelerated mineralization of soil organic matter not mentioning the ecological aspects. Most scientist agree that prolonged application of manure either stabilizes the initial content of humus or increases its content, depending on the rates of applied manure [38, 56-58].

\subsubsection{Soil mineral nitrogen in fertilization experiment}

The study of the fertilization experiment showed that amount of soil mineral $\mathrm{N}$ (min-N) was in direct correlation with added $\mathrm{N}$ (Fig 3). The highest content of min-N was recorded in MO3 and M3 treatments, followed by O, MO1and M1 treatments (Figure 3). As shown in Table 1, M3 and MO3 treatments received the highest rate of $\mathrm{N}$ that was $1350 \mathrm{~kg}$ of $\mathrm{N}$ per ha per rotation that was the reason of the increased amount of min-N. Generally, min-N was distributed proportionally to the amount of applied N. But some difference was observed between application of mineral $\mathrm{N}$ alone and combination of $\mathrm{N}$ applied with mineral fertilizer and manure. For example, M1 and MO1 treatments received the same amount of $\mathrm{N}$ in whole rotation, where $\mathrm{M} 1$ treatment received only mineral $\mathrm{N}$, and MO1 treatment received $50 \% \mathrm{~N}$ from the mineral fertilizer and $50 \% \mathrm{~N}$ from the manure. Similar pattern was observed in the case of M3 and MO3. Fertilizer N was quickly utilized by plants and microorganisms, while $\mathrm{N}$ of manure was decomposed more slowly supplying the soil with $\mathrm{N}$ for longer period. 


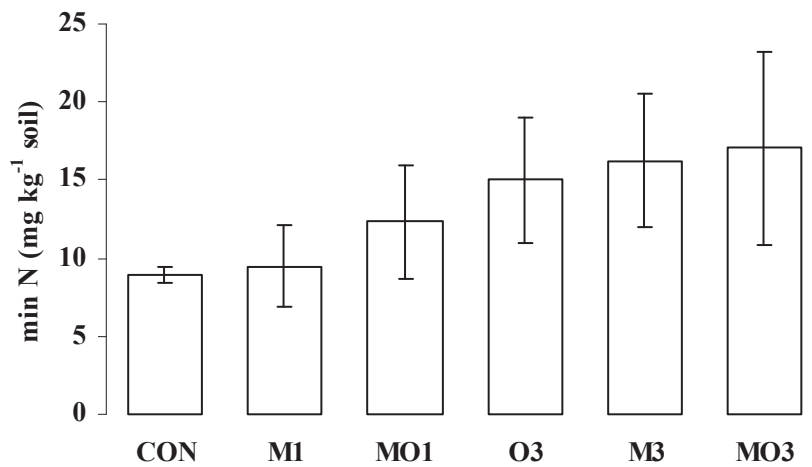

Figure 3. Soil mineral nitrogen at sampling time from fertilization treatments, Uman

The [56] reported that "ready" humic substances applied with cattle manure is thermodynamically non-stable and therefore is subject to faster decomposition and mineralization. Probably, these non-stable organic substances in manure were the main source of mineralized nitrogen resulting in increased accumulation of labile forms of $\mathrm{N}$ in manured experiment.

\subsubsection{Nitrogen mineralization potentials in fertilization experiment}

Mineralization rate constant $(k)$ among the treatments varied significantly $(P<0.05)$. The treatments where the high rates of manure wereapplied showed higher mineralization rate (Figure 4). All treatments but MO3 have lowered their mineralization rate by the end of incubation (56-70 days). MO3is the treatment that received mineral fertilizer and high rate of manure.Nitrogen of the mineral fertilizer serves as an easy available substrate for microorganisms at the beginning of the incubation then, after the available mineral nitrogen was depleted by microbial utilization, the nitrogen of the manure was exposed to microbial attack showing high mineralization rate after 70 days of incubation, while in $\mathrm{O}$ treatment, manure was attacked from the beginning because no mineral $\mathrm{N}$ was added to the soil. Manure consists of labile and non-labile fractions of organic compounds. After the labile fractions of manure were mineralized, the mineralization rate was slowed down thus showing lowered rate after eight weeks of incubation.

PMN content was the highest in the treatments where high rates of manure were applied that are $\mathrm{O}$ and MO3 (Table 4). Manure was applied about 19 months before the soil sampling. During about eight months the soil was frozen and no microbial activity was undergoing. It takes about 275 days to start releasing mineral $\mathrm{N}$ from manure, and about 391 days for complete mineralization or for reaching the stabilization point [59]. By the time of sampling manure had been releasing $\mathrm{N}$ for about 90 days, therefore, during the laboratory incu- 
bation manure continued to release mineral $\mathrm{N}$, showing higher $\mathrm{PMN}$ in $\mathrm{O}$ and $\mathrm{MO} 3$ treatments.

Cattle manure contains "ready" humic substances that can be directly and immediately involved into immobilization processes. Probably, these non-stable organic substances in manure were the main source of mineralized $N$ resulting in increased accumulation of labile forms of $\mathrm{N}$ under the manured treatments.

\begin{tabular}{|c|c|c|c|c|}
\hline Treatment & $\begin{array}{l}\text { Fertilization rates } \\
\qquad \text { kg ha }^{-1} \text { year }^{-1}\end{array}$ & $\begin{array}{c}\mathrm{PMN} \\
\mathrm{mg} \mathrm{kg}^{-1}\end{array}$ & $\mathrm{C} / \mathrm{N}$ & Soil total N as PMN, \% \\
\hline CON & No & 75.61 & 12.7 & 4.6 \\
\hline M1 & $\mathrm{N}_{45}$ & 84.64 & 8.6 & 5.2 \\
\hline M3 & $N_{135}$ & 78.50 & 15.2 & 4.5 \\
\hline $\mathrm{O}$ & Manure $\mathrm{N}_{67.5}$ & 96.44 & 12.0 & 5.4 \\
\hline MO1 & $\mathrm{N}_{22}+$ manure $\mathrm{N}_{22.5}$ & 88.17 & 13.7 & 5.2 \\
\hline $\mathrm{MO3}$ & $\mathrm{N}_{22}+$ manure $\mathrm{N}_{67.5}$ & 151.92 & 6.8 & 8.8 \\
\hline
\end{tabular}

Table 4. Potentially mineralizable nitrogen as influenced by different fertilization, Uman

\begin{tabular}{|c|c|c|c|c|c|c|}
\hline \multirow{3}{*}{$\begin{array}{l}\text { Treatment } \\
\text { CON }\end{array}$} & \multirow{3}{*}{$\begin{array}{c}\text { Fertilization rate } \\
\text { kg ha }^{-1} \text { year }^{-1}\end{array}$} & MBC & MBN & \multirow{3}{*}{$\begin{array}{c}\mathrm{C} / \mathrm{N} \\
14\end{array}$} & \multicolumn{2}{|c|}{ Soil organic C and total N (\%) } \\
\hline & & \multicolumn{2}{|c|}{$\mathrm{mg} \mathrm{kg}^{-1}$ soil } & & as $\mathrm{MBC}$ & as MBN \\
\hline & & $459 a$ & $33.3 a$ & & 2.09 & 2.02 \\
\hline M1 & $\mathrm{N}_{45}$ & $586 b$ & $35.5 a$ & 17 & 2.72 & 2.19 \\
\hline M3 & $N_{135}$ & $531 \mathrm{c}$ & $21.3 b$ & 25 & 2.35 & 1.21 \\
\hline $\mathrm{O} 3$ & Manure $\mathrm{N}_{67.5}$ & $566 b c$ & $85.3 c$ & 7 & 2.40 & 4.81 \\
\hline MO1 & $\mathrm{N}_{22}+$ manure $\mathrm{N}_{22.5}$ & $585 b$ & $71.5 d$ & 8 & 2.64 & 4.19 \\
\hline $\mathrm{MO3}$ & $\mathrm{N}_{22}+$ manure $\mathrm{N}_{67.5}$ & $677 d$ & $69.6 d$ & 10 & 3.10 & 4.05 \\
\hline
\end{tabular}

Table 5. Microbial biomass carbon (MBC) and nitrogen (MBN) as influenced by different fertilization, Uman

\subsubsection{Microbial biomass carbon and nitrogen in fertilization experiment}

Microbial biomass $\mathrm{N}(\mathrm{MBN})$ in the treatments where manure was applied amounted from 72 to $85 \mathrm{mg} \mathrm{kg}^{-1}$ soil (Table 5). In the treatments where no manure was applied MBN amounted from 21 to $36 \mathrm{mg} \mathrm{kg}^{-1}$ soil. Moreover, application of the high rate of mineral fertilizer alone decreased the MBN content. The ratio of MBC to MBN also shows distinctive difference between the treatments where high ratio was observed under the mineral fertilization and lower ratio under the manure application. Noticeably, highest $\mathrm{C}$ to $\mathrm{N}$ ratio 
was under the highest rate of mineral fertilization (M3) and the lowest was under the high rate of manure application (O3). This is due to intensive utilization of added nitrogen by microorganisms. Addition of biomass substrate with the content $\mathrm{N}$ more than 1.5 to $1,7 \%$ do not need additional fertilizer by nitrogen, the soil $\mathrm{N}$ satisfies the need of microorganisms during the decomposition. Always, the "requirements" of microorganisms are satisfied first of all, disregarding on the need of plants for nitrogen.

\section{Low rate fertilization (M1)}

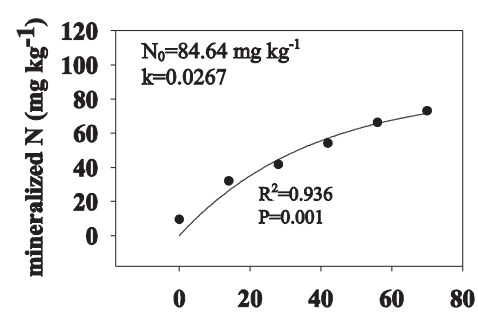

High rate fertilization (M3)

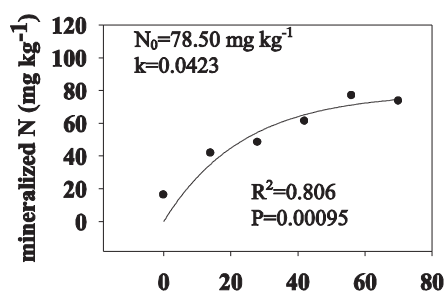

Control (CON)

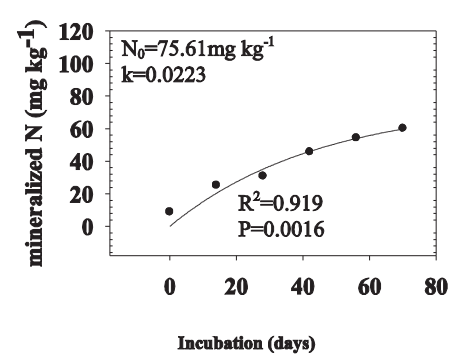

Low rates of fertilization and manure application (OM1)

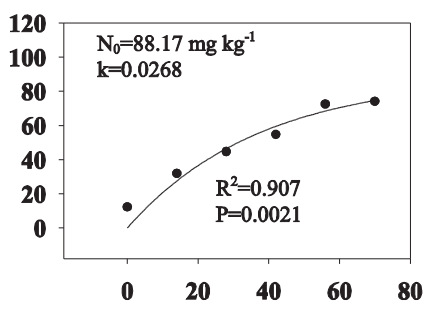

High rates of fertilization and manure application (OM3)

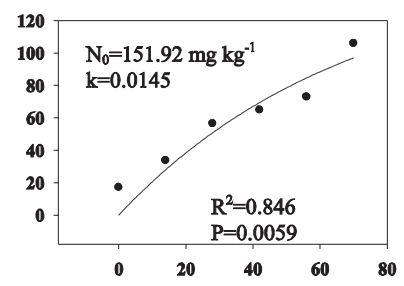

Manure (O)

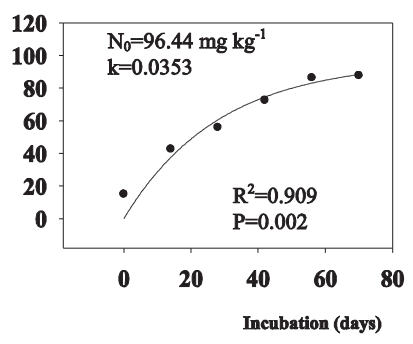

Figure 4. Fitting curves of nitrogen mineralization in fertilization experiment in Uman, Ukraine, as described with the first order kinetic model: $\mathrm{Nmin}=\mathrm{N}_{0}\left(1-\mathrm{e}^{-k t}\right)$, where $\mathrm{Nmin}$ is the mineralized $\mathrm{N}$ at time $t, \mathrm{~N}_{0}$ is the potentially mineralizable $\mathrm{N}(\mathrm{PMN}), \mathrm{k}$ is the mineralization rate constant. 


\subsection{Impact of fertilization and irrigation practices on total soil organic $\mathrm{C}$ and $\mathbf{N}$}

This study was conducted in long-term experiments with fertilization and irrigation in Kherson, south Ukraine. Sampling scheme of the Kherson experiments were 1) irrigated plus fertilized treatment (I+F), 2) irrigated only (I); 3) fertilized only (F) and 4) control that was neither fertilized nor irrigated (CON).

Analysis of variance showed that soil organic carbon (SOC) and total nitrogen (TN) were not statistically different among treatments. However, there were observed a different trend in accumulating SOM (Table 6). Contents of SOC and TN were for $7.19 \%$ and $9.30 \%$ respectively, greater in I+F treatments than in the control CON. Higher accumulation of SOC and TN under I+F treatment is due to higher biomass production under irrigation and fertilization. Consequently, higher plant biomass contributes to SOM. Fertilization (F) alone, or irrigation (I) alone maintained similar amount of organic $\mathrm{C}$ and total N. Kherson region is characterized with very small amount of precipitation, around $300 \mathrm{~mm}$ annually. In such dry conditions, fertilization does not pay off in terms biomass production because the applied fertilizer cannot be dissolved and be available for plant consumption.

\begin{tabular}{|c|c|c|c|c|}
\hline \multirow[t]{2}{*}{ Treatments } & \multirow[t]{2}{*}{ Applied treatment } & Organic C & Total N & \multirow[t]{2}{*}{$\mathrm{C} / \mathrm{N}$} \\
\hline & & \multicolumn{2}{|c|}{$\mathrm{g} \mathrm{kg}^{-1}$ soil } & \\
\hline $\mathrm{I}+\mathrm{F}$ & Irrigated and fertilized & $16.7 a$ & $1.29 a$ & 13 \\
\hline $\mathrm{F}$ & Fertilized & $16.4 a$ & $1.25 a$ & 13 \\
\hline I & Irrigated & $15.8 \mathrm{a}$ & $1.24 a$ & 13 \\
\hline CON & no & $15.5 a$ & $1.17 a$ & 13 \\
\hline
\end{tabular}

Table 6. Organic carbon and total nitrogen concentration in irrigation experiment, Kherson

\subsubsection{Soil mineral nitrogen in irrigation experiment}

Content of soil mineral $\mathrm{N}$ was different among the treatments at $P=0.1$ (Fig. 5). As expected, the greatest differences were observed between $\mathrm{I}+\mathrm{F}$ and non-irrigated treatments ( $\mathrm{F}$ and $\mathrm{CON})$.

Irrigated treatment accumulated higher min- $\mathrm{N}$ than the non-irrigated because irrigation of dry soil resulted in flash in microbial growth. During the long dry period the most of microorganisms dies, and then later upon irrigation those microbial necromass serves as easy source of $\mathrm{N}$ for survived microorganisms. The microorganism's body has the narrowest $\mathrm{C}-$ to- $\mathrm{N}$ ratio that is an indicator of the most easily available $\mathrm{N}$ source. Thus the flash in microbial growth accelerates mineralization processes in soil and moistening of dry soil causes disruption of organic compounds and soil particles that may contain organic substances. Subsequently, the disrupted organic material is more sensitive for microbial attack thus contributing to $\mathrm{N}$ mineralization. 

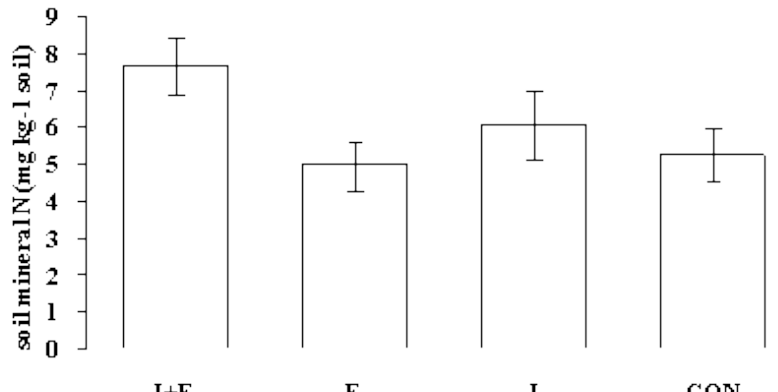

$\mathrm{I}+\mathrm{F}$

F

I

$\mathrm{CON}$

Figure 5. Soil mineral nitrogen in irrigation experiment, Kherson

\subsubsection{Nitrogen mineralization potentials in irrigation experiment}

Potentially mineralizable nitrogen $(P M N)$ was significantly different $(P=0.01)$ among the treatments with the highest mineralization rate under I+Ftreatment $(\mathrm{k}=0.0192)$ (Figure 6). The highest accumulation of mineralizable N (PMN) was also obtained under the I+Ftreatment (171.73 $\mathrm{mg} \mathrm{kg}^{-1}$ ) (Table 7), while all other treatments maintained statistically not different amounts of PMN.

Irrigation and fertilization (I+F)

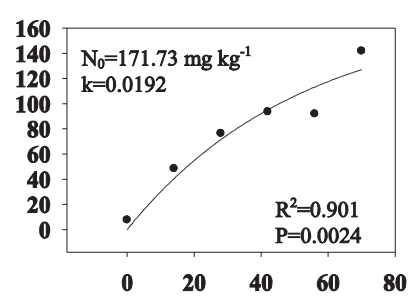

Irrigation (I)

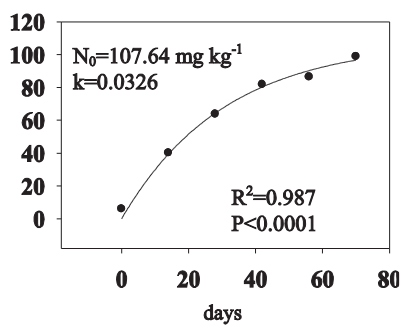

Fertilization (F)

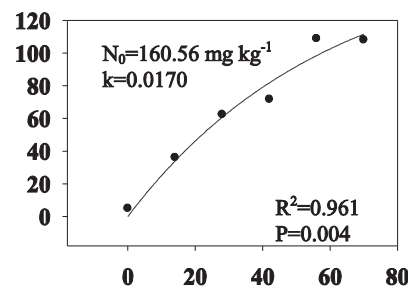

Control (CON)

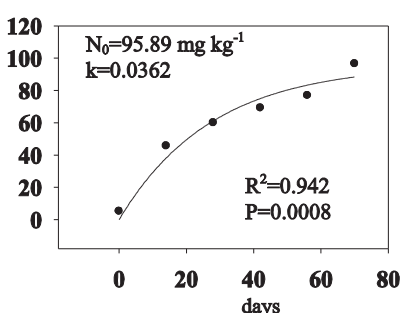

Figure 6. Fitting curves of nitrogen mineralization in fertilization experiment, Kherson, as described by the first order kinetic model: $\mathrm{Nmin}=\mathrm{N}_{0}\left(1-\mathrm{e}^{-\mathrm{k} t}\right)$, where $\mathrm{Nmin}$ is the mineralized $\mathrm{N}$ at time $t, \mathrm{~N}_{0}$ is the potentially mineralizable $\mathrm{N}$ (PMN), $\mathrm{k}$ is the mineralization rate constant 
I + F treatment maintained higher plant biomass returned into soil. Later when the soil was placed under the favourable laboratory conditions, those accumulated residues were subjected to mineralization showing higher PMN.

Fertilization alone (F) had suppressed mineralization on the field because of deficiency of water necessary for microbial activity. But when the soil was placed under favourable laboratory conditions the accumulated organic substrate is mineralized, thus giving nearly the same amount of PMN as the irrigated treatment.

\subsubsection{Carbon mineralization potentials in irrigation experiment}

Irrigated plus fertilized treatment $(\mathrm{I}+\mathrm{F})$ showed the highest carbon mineralization rate as well as amount of PMC in 70d (Fig. 7; Table 7). Irrigation of dry soil disrupts soil structure thereby making previously sequestered carbon available for microbial utilization. The [60, 61] found that soil drying destroyed $1 / 3$ to $1 / 4$ of biomass and after remoistening the biomass was progressively restored to approximately the same size as before drying.

Irrigation and fertilization (I+F)

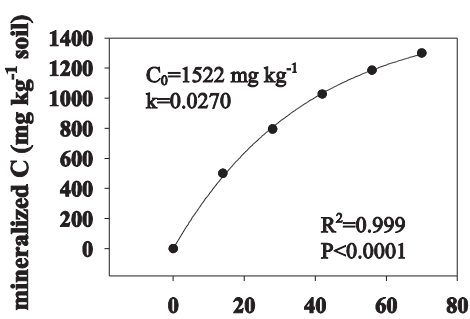

Irrigation (I)

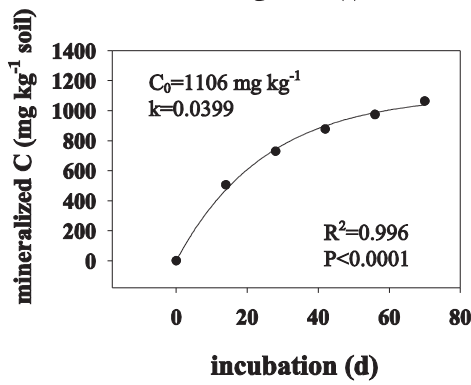

\section{Fertilization (F)}

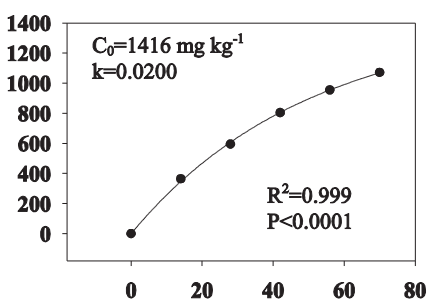

Control (CON)

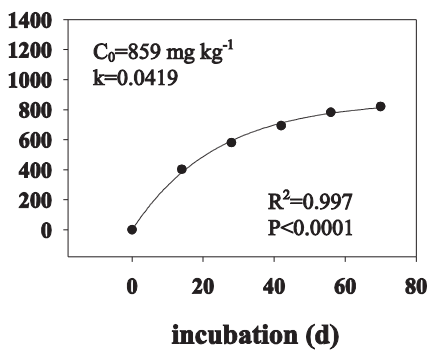

Figure 7. Fitting curves of carbon mineralization in fertilization experiment, Kherson, as described by the first order kinetic model: $C \min =C_{0}\left(1-e^{-k t}\right)$, where $C$ min is the mineralized $C$ at time $t, C_{0}$ is the potentially mineralizable $C$ (PMC), $k$ is the mineralization rate constant 
In this study, high temperatures and dry conditions have caused death of microorganisms that were immobilized during desiccation via adsorption on clay surfaces and/or transformation into other forms of organic compounds. Then, the following irrigation revived microbial community and disrupted soil clay particles that released stabilized organic matter. In the study conducted by [62] the similar results were obtained, where extra mineralized ${ }^{14} \mathrm{C}$, due to soil desiccation came from non-living residues, likely to be those that were stabilized by adsorption to clay surfaces.

The highest percentage of PMC and PMN in soil organic C were under I+F treatment (Table 7). This is in accordance with the earlier discussion and confirms the hypothesis that there are at least two reasons responsible for it: firstly, irrigation of dry soil causes enhanced mineralization of soil organic matter, and secondly, fertilization of irrigated soil provides higher plant biomass that contributes to the accumulation of labile organic matter.

\begin{tabular}{|c|c|c|c|c|c|c|}
\hline \multirow[t]{2}{*}{ Treatments } & \multirow[t]{2}{*}{ Applied treatment } & \multicolumn{2}{|l|}{ PMC } & \multirow[t]{2}{*}{$\mathrm{C} / \mathrm{N}$} & \multicolumn{2}{|c|}{$\begin{array}{c}\text { Soil organic C } \\
\text { and total N (\%) }\end{array}$} \\
\hline & & \multicolumn{2}{|c|}{$\mathrm{mg} \mathrm{kg}^{-1}$ soil } & & as PMC & as PMN \\
\hline $\mathrm{I}+\mathrm{F}$ & Irrigated and fertilized & 1522 & 171.73 & 8.9 & 9.11 & 13.31 \\
\hline $\mathrm{F}$ & Fertilized & 1416 & 160.56 & 8.8 & 8.63 & 12.84 \\
\hline I & Irrigated & 1105 & 107.64 & 10.2 & 6.99 & 8.68 \\
\hline CON & no & 858 & 95.89 & 8.9 & 5.53 & 8.20 \\
\hline
\end{tabular}

Table 7. Mineralizable carbon and nitrogen (PMC and PMN) in irrigation experiment, Kherson

\subsection{4. "Light fraction" organic matter in irrigation experiment, Kherson}

The I+Ftreatment maintained the highest amount of 'light' fraction dry matter (LFDM), carbon (LFC), nitrogen (LFN) and their proportions in soil organic carbon (SOC) and total nitrogen (TN) (Table 8). One of the reasons is, as discussed earlier, higher biomass production in this treatment, hence higher organic substrate was added with residues. Desiccation that caused the death of a large number of microorganisms, followed by immobilization and condensation of their dead tissues thus increasing the amount of recalcitrant, soluble organic $C$ is another reason [60]. Moreover, irrigation of desiccated soil also causes the death of microorganisms due to the osmoregulatory shock [63] that also could contribute to the LFOM.

\subsubsection{Microbial biomass in irrigation experiment, Kherson}

Microbial biomass carbon (MBC) and nitrogen (MBN) significantly differed among the treatments (Table 9). The highest MBC and MBN were obtained under the irrigation alone (I) treatment followed by the irrigated plus fertilized (I+F) treatment. The least microbial biomass was obtained under the fertilized alone $(\mathrm{F})$ treatment. 


\begin{tabular}{|c|c|c|c|c|c|c|c|}
\hline \multirow[t]{2}{*}{ Treatment } & \multirow[t]{2}{*}{ Applied treatment } & LFDM & \multirow[t]{2}{*}{ LFC } & LFN & \multirow[t]{2}{*}{$\mathrm{C} / \mathrm{N}$} & \multicolumn{2}{|c|}{$\begin{array}{c}\text { Soil organic C } \\
\text { and total N (\%) }\end{array}$} \\
\hline & & $\mathrm{g} \mathrm{mg}^{-1}$ soil & & $\mathrm{mg} \mathrm{kg}^{-1}$ soil & & as LFC & as LFN \\
\hline $\mathrm{I}+\mathrm{F}$ & Irrigated and fertilized & 9.27 & 1884 & 122 & 15 & 11.3 & 9.4 \\
\hline $\mathrm{F}$ & Fertilized & 8.52 & 1591 & 104 & 15 & 9.7 & 8.4 \\
\hline 1 & Irrigated & 6.49 & 1589 & 104 & 15 & 10.0 & 8.4 \\
\hline CON & no & 6.82 & 1684 & 108 & 16 & 10.8 & 9.2 \\
\hline
\end{tabular}

Table 8. "Light fraction" dry matter (LFDM), carbon (LFC) and nitrogen (LFN) in irrigation experiment, Kherson

\begin{tabular}{|c|c|c|c|c|c|c|}
\hline \multirow[t]{2}{*}{ Treatment } & \multirow[t]{2}{*}{ Applied treatment } & $\mathrm{MBC}$ & MBN & \multirow[t]{2}{*}{$\mathrm{C} / \mathrm{N}$} & \multicolumn{2}{|c|}{ Soil organic C and total $\mathrm{N}(\%)$} \\
\hline & & \multicolumn{2}{|c|}{$\mathrm{mg} \mathrm{kg}^{-1}$ soil } & & as $\mathrm{MBC}$ & as MBN \\
\hline $\mathrm{I}+\mathrm{F}$ & Irrigated and fertilized & 618 & 160 & 4 & 3.7 & 12.4 \\
\hline $\mathrm{F}$ & Fertilized & 450 & 76 & 6 & 2.7 & 6.1 \\
\hline I & Irrigated & 733 & 175 & 4 & 4.6 & 14.2 \\
\hline CON & no & 636 & 128 & 5 & 4.1 & 10.9 \\
\hline
\end{tabular}

Table 9. Microbial biomass in irrigation experiment, Kherson

Such distribution of microbial biomass was expected because moisture conditions are a major factor controlling survival and activity of microorganisms in the soil [64]. Drying and remoistening of soils strongly affects microbial growth and activity [61, 65, 66]. After remoistening of dried soil, available $\mathrm{C}$ components were assimilated and transformed partly into new biomass $\mathrm{C}$, and partly involved into $\mathrm{CO}_{2}$ that evolved into the atmosphere [63].

\subsubsection{General discussion of fertilization, manure application and irrigation experiments}

Many researchers recorded positive effects of manure application on SOM [38, 57, 67-69]. For example, in Nebraska, annual application of $13.5 \mathrm{t} \mathrm{ha}^{-1}$ of manure (dry matter) during 31 years on irrigated land has increased content of humus from 0.98 to $1.67 \%$. The [59] found out that increased application of manure resulted in intensification of $\mathrm{C}$ mineralization, especially the $C$ that is included in fulvic acids, and in lesser extent in humic acids. Biological analysis showed that application of high rates of manure activates the biochemical processes, which is controlled by particular microbiological community that has ability for active transformations not of only simple organic substances (e.g. fulvic acids), but also of more complex and hardly decomposable substances (e.g. humic acid).

Increased microbial activity in irrigated treatments in Kherson has been ascribed to the rapid metabolization of biomass-derived substrate resulting from the death of part of the microbial community during drying [61-63, 70] and/or rapid rewetting of the desiccated soil material [100]. Alternate drying and re-moistening increases the mobility of organic matter and results in the release of $\mathrm{N}$ as ammonium and amides [42]. 


\subsection{Impact of bare fallow on soil labile organic matter in Haplustolls, Astana, Kazakhstan}

With increasing cultivation intensity, the SOM of the less stable pools is decomposed, as indicated by decreasing portions of sand-sized SOM (2-0.05 mm) [19, 46, 47], or light fraction $\mathrm{C}[48,49)$. Organic compounds adsorbed to surfaces of clay particles might become exposed to microbial attack after disruption of aggregates due to tillage.

To investigate the impact of bare fallow on soil SOM dynamics the five representatives fallow-spring wheat crop rotation were selected (2-year, 4-year and 6-year with one year of bare fallowing). Soil samples were collected from pre- (2R-pre, 4R-pre and 6R-pre) and postfallow (2R-post, $4 \mathrm{R}$-post and 6R-post) phases in each rotation. The continuous fallowing (CF) and continuous cropping of wheat (CW) were also sampled to see the effect of fallow impact on SOM.

\subsubsection{Soil mineral nitrogen in fallow frequency experiment}

On a long-term basis, the CF system accumulated the highest amount of soil mineral nitrogen (min-N). But min-N was strongly affected by summer fallow on a short-term basis as well. Pre- and post-fallow phases showed significant differences with min-N accumulating in post-fallow than in pre-fallow phase (Table 10). Post-fallow phases accumulated 3.0-, 1.9and 1.9-fold amounts of min-N of pre-fallow phases in $2 \mathrm{R}, 4 \mathrm{R}$ and $6 \mathrm{R}$, respectively

As expected, the CF system maintained the highest amount of soil min- $\mathrm{N}$ that was due to enhanced mineralization of SOM compared to the other systems. The short-term effect of fallow on the accumulation of min-N is clearly observed as well. During fallow phase min-N is not subjected to either plant uptake or leaching, thus resulting in a greater accumulation of soil min-N in post-fallow (2R-post, $4 \mathrm{R}$-post and $6 \mathrm{R}$-post) than in pre-fallow phases (2Rpre, 4R-pre and 6R-pre).

\subsubsection{Nitrogen mineralization potentials in fallow frequency experiment (PMN)}

The pattern of $\mathrm{N}$ mineralization showed a different trend between pre- and post-fallow phases in all rotations (Fig. 8). Pre-fallow phases (Fig.8. a, c and e) were characterized by a larger value of PMN $\left(N_{0}\right)$, a smaller mineralization rate constant $(\mathrm{k})$, and a shorter initial delay of mineralization (c) than in the post-fallow phases (Fig.8. b, d, and f).

Fallow influenced accumulation of PMN on short-term basis, that is, pre-fallow phases (2Rpre, 4R-pre and 6R-pre) accumulated more PMN than post-fallow (2R-post, 4R-post and 6Rpost) phases (Table 10). The lowest PMN was observed under the CF system (69 $\left.\mathrm{mg} \mathrm{kg}^{-1}\right)$ and the highest under 6R-pre (124 $\left.\mathrm{mg} \mathrm{kg}^{-1}\right)$. Pre-fallow phases accumulated 2.4, 1.3 and 1.5 fold amount of PMN of post-fallow phases in $2 R, 4 R$ and $6 R$, respectively. Larger amounts of mineralized nitrogen $\left(N_{0}\right)$ in the pre-fallow phases indicate larger storage of PMN in these soils than in post-fallow soils. Differences in the rate constant $(k)$ between pre- and post-fallow phases indicate that fallowing has caused changes in the quality of the PMN.

Due to multiple cultivations of fallows the soil is subjected to alternating wet-dry cycles. The wet period provided better moisture condition microorganism activity and produced great- 
er biomass than in cropped fields. Then in the subsequent dry period the greater biomass turned into necromass due to drought. This cycle may be repeated several times in a cropping season. Later, during incubation in the laboratory, this microbial necromass as well as living biomass was rapidly mineralized showing a higher mineralization rate constant in the post fallow than in the pre-fallow phases. The soils from the post-fallow phase showed a longer initial delay of mineralization, suggesting that higher concentration of min-N compared to pre-fallow phase probably stimulated microbial activity and resulted in immobilization of mineralized $\mathrm{N}$ during the initial stages of incubation.

The long-term effect of fallow was not observed for soil min-N or PMN suggesting that $\mathrm{N}$ mineralization is only affected by the substrate added during the previous year or the latest cycle of rotation. Nitrogen in the forms of $\mathrm{NO}_{3}{ }^{-}$and $\mathrm{NH}_{4}{ }^{+}$is assimilated by plants and returned into soil whereas $\mathrm{C}$ originates from $\mathrm{CO}_{2}$ in the air and ploughed as organic residue into soil. Nitrogen transformations are closely related to the processes of mineralization of its organic forms in plant-soil system. Therefore, in plant-soil systems $\mathrm{N}$ cycling is affected over shorter period than C cycling.

\begin{tabular}{|c|c|c|c|c|c|c|}
\hline \multirow[t]{2}{*}{$\begin{array}{c}\text { Rotation } \\
\text { phase }\end{array}$} & PMC & $\min -\mathrm{N}$ & PMN & \multirow[t]{2}{*}{ C-to-N ratio } & $\begin{array}{c}\text { Organic C } \\
\text { as PMC }\end{array}$ & $\begin{array}{l}\text { Total } \mathbf{N} \\
\text { as PMN }\end{array}$ \\
\hline & & $\mathrm{g} \mathrm{kg}^{-1} \mathrm{so}$ & & & \multicolumn{2}{|c|}{$\%$} \\
\hline$C F$ & $794 b^{x}$ & $46 a$ & $69 a$ & 11 & 3.6 & 3.5 \\
\hline 2R-pre & 1194ab & $14 b$ & $166 b$ & 7 & 4.7 & 7.4 \\
\hline 2R-post & $1012 b$ & $42 a$ & $69 a$ & 15 & 4.0 & 3.2 \\
\hline 4R-pre & $1224 a$ & $13 b$ & $86 c$ & 14 & 4.7 & 3.8 \\
\hline 4R-post & $1215 a$ & $24 c$ & $67 a$ & 18 & 4.9 & 3.1 \\
\hline 6R-pre & $1524 c$ & $16 b$ & $124 b$ & 12 & 4.9 & 4.8 \\
\hline 6R-post & $1300 a c$ & $30 c$ & $82 c$ & 16 & 4.3 & 3.3 \\
\hline $\mathrm{CW}$ & $1581 c$ & $14 b$ & $93 c$ & 17 & 5.8 & 3.9 \\
\hline
\end{tabular}

Table 10. Effect of fallow frequency and rotation phase on labile organic matter content, Astana

\subsubsection{Carbon mineralization potentials in fallow frequency experiment, Astana}

Differences in PMC among the rotation systems $(P<0.001)$ were more clearly shown than for SOC. PMC ranged from $3.6(\mathrm{CF})$ to $5.8 \%(\mathrm{CW})$ of the SOC. The amount of PMC was more affected by the long-term effect of fallow than by the short-term effect and was inversely proportional to fallow frequency.

Continuous wheat (CW) and 6-y systems (6R) had higher amount of PMC that was inversely proportional to fallow frequency and indicated the long-term effect of fallow. These results corroborate with the study conducted by [73] who found for a silt-loam in southwestern Saskatchewan that mineralized C (measured after 30 days at $21^{\circ} \mathrm{C}$ ) represented 1.06 and $1.45 \%$ of SOC in a $2-y$ fallow-wheat rotation and continuous growing of wheat, 
respectively. The [74] found that $C$ mineralization was not related to the amount of crop residue from the previous year. In our study PMC was a little higher in the pre-fallow (2R-pre, $4 \mathrm{R}$-pre and 6R-pre) than in the post-fallow (2R-post, 4R-post and 6R-post) phases, probably reflecting the input of crop and weed residues in the preceding year.

(a) Pre-fallow phase in 2-y rotation (2R-pre)

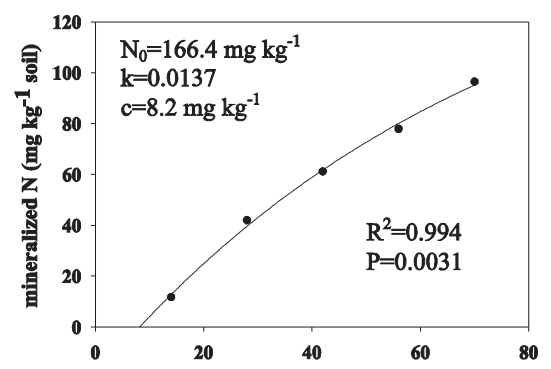

(c) Pre-fallow phase in 4-y rotation (4R-pre)

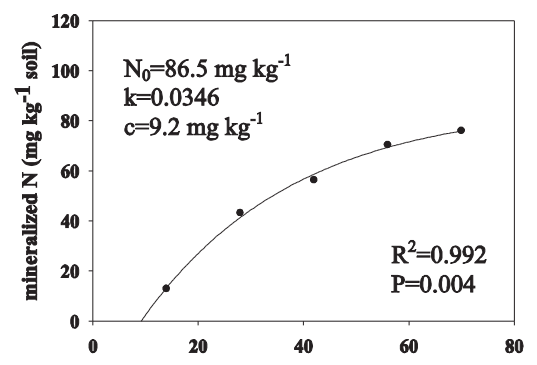

(e) Pre-fallow phase in 6-y rotation (6R-pre)

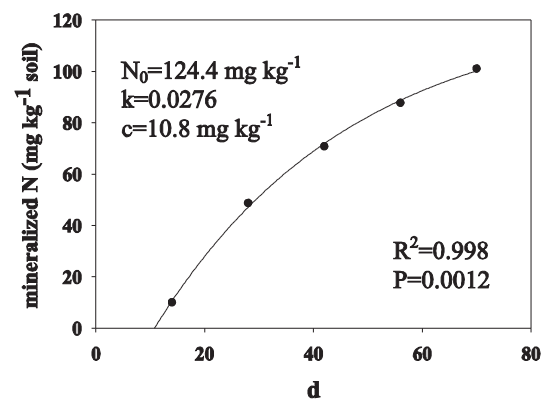

(b) Post-fallow phase in 2-y rotation (2R-post)

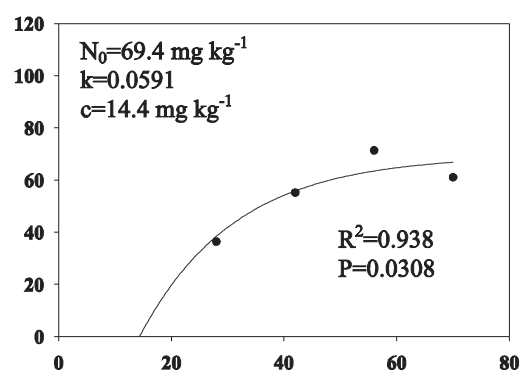

(d) Post-fallow phase in 4-y rotation (4R-post)

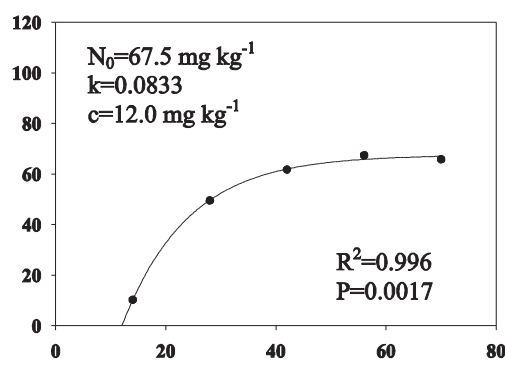

(f) Post-fallow phase in 6-y rotation (6R-post)

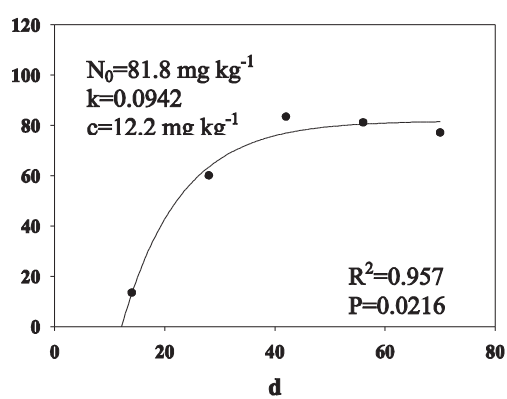

Figure 8. Fitting curves of $\mathrm{N}$ mineralization from pre- and post-fallow phases of the 2-, 4-, and 6-year wheat-fallow 40years rotation experiment, as described by the first order kinetic model with an initial delay of mineralization $\left(N_{\min }=\right.$ $N_{0}\left(1-e^{-k t-c}\right)$, where, $N_{\min }$ is mineralized $\mathrm{N}$ at time $t_{1 ;} N_{0}$ is value of potentially mineralizable $\mathrm{N}(\mathrm{PMN}), k$ is a mineralization rate constant, and $\mathrm{c}$ is an initial delay in mineralization. 


\subsubsection{Light fraction" organic matter in fallow frequency experiment, Astana}

The amount LF-OM was highly responsive to fallow frequency, accounting for $1.1(\mathrm{CF})-6.3(\mathrm{CW}) \%$ of the SOC and $0.8(\mathrm{CF})-4.3(\mathrm{CW}) \%$ of the TN (Table 11). LF-OM, as expressed on the basis of dry matter (LF-DM), C (LF-C) or N (LF-N), was inversely related to fallow frequency. For example, the LF-C content of the CW system was 7.2 times higher than that in the CF system. These results agree with those of other studies [e.g. 36, 75], where LF content was highest under continuous cropping and lowest in those with a high frequency of summer fallow. Additionally, LF-C was affected by the rotation phase, showing larger amounts in pre- than in post-fallow phases in $4 \mathrm{R}$ and $6 \mathrm{R}$ rotations.

"Light fraction" of SOM (LF-OM) consists mainly of plant residues, small animals and microorganisms adhering to plant-derived particulate matter at various stages of decomposition that serves as a readily decomposable substrate for soil microorganisms and also as a short-term reservoir of plant nutrients [76]. The "light fraction' C (LF-C) was positively correlated with PMC (Fig. 9), and confirm the hypothesis that the reduced fallowing system has more potential to supply soil with easily mineralizable C. However, there was no linear correlation between LF-N and PMN, presumably because the high C-to-N ratio of the LF-OM temporary induced $\mathrm{N}$ immobilization [36].

The content of labile OM, which is closely related to LF-OM, may be governed by the degree to which temperature and moisture conditions constrain decomposition of accumulated residues [52]. Under the CW system decomposition of residues during periods of favourable soil temperature was retarded by the depleted soil moisture [77, 78,]. Then, when moisture and temperature constraints were removed during laboratory incubations, soil showed a high respiration rate [36]. On the contrary, residues in the $2 \mathrm{R}$ system during the fallow phase were always exposed to an extended period with favourable moisture and temperature. Therefore, labile organic matter was rapidly depleted in the field, and in the laboratory respiration rates were much lower in $2 \mathrm{R}$ than in CW [52].

\subsection{Grain yield and weed biomass}

The main controller of biological activity in soil is the SOM generated from crop residue, while crop residues are in direct correlation with crop yield and sometimes with yield of weeds. In systems with no pesticide application, such as control treatments, or in case of the CW (continuous wheat cropping), where no break in lifecycle of weeds occur, the weed biomass might significantly contribute to the input of crop residue in soil and affect the crop yield output.

The highest grain yield was produced in the first year of the rotations (the year after fallow) (Figure 10). However, the yield decreased sharply with in the second and successive years after fallowing. This trend is, firstly, because plants in a post-fallow phase take advantage of higher soil min-N. Secondly, because when a field is in fallow provides the only break for weed infestation; the amount of weeds was generally least in the first year after fallow and reduced competition for nutrients. In contrast to the grain yield, weed infestation reached its 


\begin{tabular}{|c|c|c|c|c|c|c|}
\hline \multirow[t]{2}{*}{$\begin{array}{c}\text { Rotation } \\
\text { phase }\end{array}$} & LF-DM & LF-C & LF-N & \multirow[t]{2}{*}{ C-to-N ratio } & $\begin{array}{c}\text { Soil C as } \\
\text { LF-C }\end{array}$ & \multirow[t]{2}{*}{$\begin{array}{c}\text { Soil } N \text { as } \\
\text { LF-N }\end{array}$} \\
\hline & $\mathrm{g} \mathrm{kg}^{-1}$ soil & \multicolumn{2}{|c|}{$\mathrm{mg} \mathrm{kg}^{-1}$ soil } & & $\%$ & \\
\hline $\mathrm{CF}$ & 0.9 & $240 a^{x}$ & $15 a$ & 16 & 1.1 & 0.8 \\
\hline 2R-pre & 3.6 & $810 b$ & $51 b$ & 18 & 3.2 & 2.2 \\
\hline 2R-post & 2.5 & $660 b$ & $38 b c$ & 16 & 2.6 & 1.7 \\
\hline 4R-pre & 5.7 & $1330 c$ & $81 d$ & 17 & 5.1 & 3.6 \\
\hline 4R-post & 5.3 & $1250 c$ & $73 d$ & 17 & 5.0 & 3.3 \\
\hline 6R-pre & 6.4 & $1560 d$ & $74 d$ & 20 & 5.1 & 3.0 \\
\hline 6R-post & 6.0 & $1500 d$ & $75 d$ & 21 & 4.9 & 2.9 \\
\hline $\mathrm{CW}$ & 7.4 & $1730 \mathrm{e}$ & $103 e$ & 17 & 6.3 & 4.3 \\
\hline
\end{tabular}

$x_{a}$-e: values within columns followed by the same letter are not significantly different $(P<0.005)$ as determined by $L S D$ analysis.

Table 11. Effects of fallow frequency and rotation phase on the amount of "light fraction" dry matter (LF-DM), "light fraction" C and N (LF-C and LF-N) and their proportions in SOC and TN in surface soil of Haplustolls, Astana
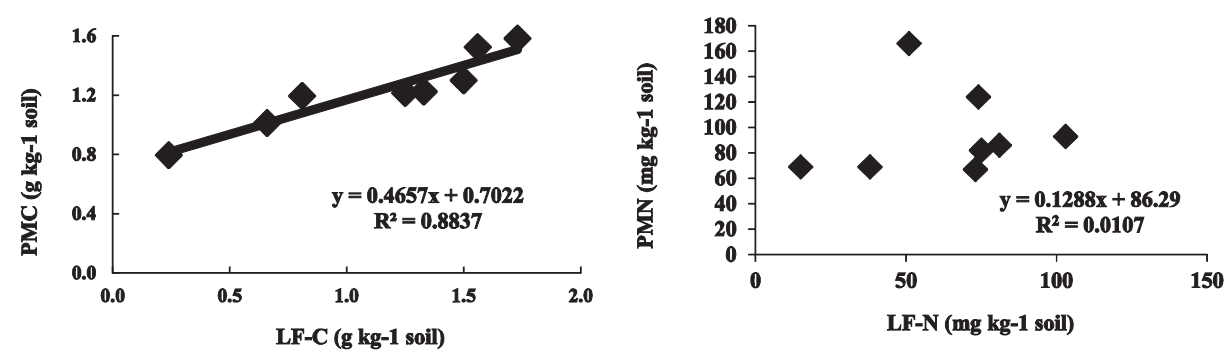

Figure 9. Correlation of potential mineralizable C and N) with "light" fraction C (LF-C) and N (LF-N)

maximum in the second years after fallow in 4R and 6R. Probably, some of the weeds were not destroyed during the fallow and their seeds remained dormant but germinated in the second year after fallow. Correlation between the grain yield and weed infestation (average for ten years) is presented by the following equation of multiple linear regression:

$Y=20.82-0.189 X$

where $X$ total amount of weeds, pieces $/ \mathrm{m}^{-2}$. The coefficient of determination was also high $\left(R^{2}=0.78\right)$ or $78 \%$ of changes of the yield depend on weed infestation. 


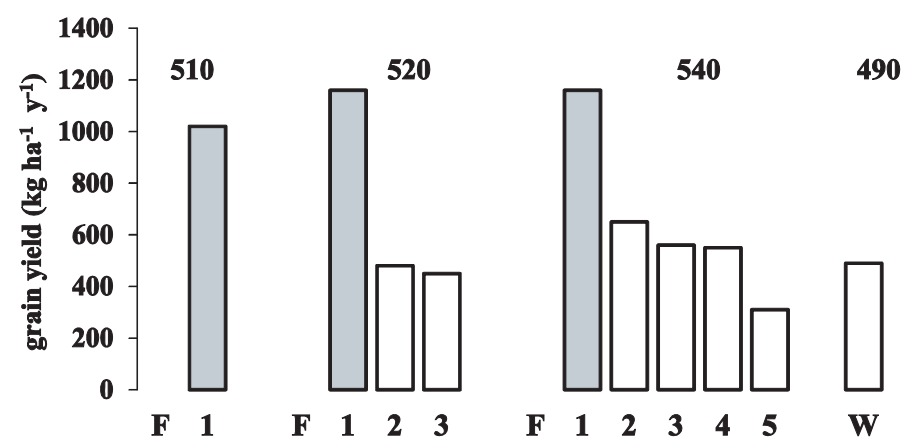

Figure 10. Grain yield (1994-2000) of spring wheat affected by distance from fallowing year. (F is fallow; 1, 2, 3...5 are succession of crops after fallow. (the numbers above bars are average yield per rotation including the fallow year).

The highest grain output per whole rotation, was obtained by 6-year rotation, being $540 \mathrm{~kg}$ $\mathrm{ha}^{-1}$ that parallels the distribution of soil labile C (PMC and LF-C). These results indicate that longer rotations with fewer fallows contribute more to the accumulation of SOM than shorter rotations with frequent fallowing, and that SOM is replenished continuously under less bare-fallowing system.

The results on Mollisols in North Kazakhstan suggested that $\mathrm{N}$ dynamics were closely related to the recent input of substrate added as plant residue while $C$ dynamics were more related to long-term substrate addition.

Yearly input of plant residue in a 6-y wheat-fallow rotation system built up more labile OM, especially LF-C or readily decomposable C, whereas 2-y rotation system with a high frequency of fallow depleted SOM via accelerated mineralization. Therefore, with no fertilizer or pesticides application, in the semi-arid regions of northern Kazakhstan, the inclusion of fallow in wheat monoculture every 6 years is the most appropriate farming system in terms of sustainability in both grain production and soil fertility.

The results of this study may provide prediction of SOM response to fallow frequency in wheat-based rotation systems in Chernozem soils of semi-arid regions: the susceptibility of labile fractions of $\mathrm{OM}$ and their relationship to fallow frequency suggest the possibility of managing labile OM through controlling the length of wheat-fallow rotation systems.

\section{Characterization of soil organic matter dynamics from different climatic zones}

Many studies have shown that climatic factors, namely temperature and precipitation are major determinants of microbial diversity and activity in soil at global [79[, regional [5, 80] and local [81] scales [47, 82]. The great meridian and latitudinal extension of Mollisols [83] determines a wide variety of climatic conditions that influence the main genetic characteris- 
tics of soils and their natural growth and agronomic properties. The aim of this study was to find out effects of temperature and moisture on soil organic matter accumulation and decomposition.The study conducted by [109] also showed that in dry and cold conditions of dry steppe, soil respiration was mostly controlled by soil temperature while residue input was a function of moisture conditions.

Four types of Mollisols from four different climatic regions were sampled: Hupludolls (southern forest-steppe, Kharkov, Ukraine), Argiudolls (northern forest-steppe, Uman, Ukraine), Calciustolls (southern steppe, Kherson, Ukraine) and Haplustolls(northern steppe, Astana, Kazakhstan) (Table 12). The sampling sites represent the most typical soil type and ecosystem for each given region. The selected geographical regions are characterized as wet-frigid (Kharkov; $6.5^{\circ} \mathrm{C}$, mean annual temperature, $542 \mathrm{~mm}$, mean annual precipitation), wet-mesic (Uman; $8.5^{\circ} \mathrm{C}, 660 \mathrm{~mm}$ ), dry-thermic (Kherson; $11^{\circ} \mathrm{C}, 332 \mathrm{~mm}$ ) and dry-frigid (Astana; $0^{\circ} \mathrm{C}$, $324 \mathrm{~mm})$.

\begin{tabular}{|c|c|c|c|c|c|c|c|}
\hline \multirow[t]{2}{*}{ Site } & \multirow[t]{2}{*}{$\begin{array}{l}\text { Geographical } \\
\text { coordinates }\end{array}$} & \multirow[t]{2}{*}{$\begin{array}{l}\text { Precipitation } \\
\qquad(\mathrm{mm})\end{array}$} & \multicolumn{2}{|c|}{$\begin{array}{c}\text { Mean temperature, } \\
\left({ }^{\circ} \mathrm{C}\right)\end{array}$} & \multicolumn{2}{|c|}{$\begin{array}{l}\text { Ecological and climatic } \\
\text { region }\end{array}$} & \multirow[t]{2}{*}{$\begin{array}{c}\text { Soil Taxonomy, } \\
\text { USDA }\end{array}$} \\
\hline & & & winter & summer & & & \\
\hline Kharkov & $50^{\circ} \mathrm{N}, 36^{\circ} \mathrm{E}$ & $515-570$ & -10 & +18 & $\begin{array}{c}\text { southern } \\
\text { forest-steppe }\end{array}$ & wet-frigid & Hapludolls \\
\hline Uman & $48.8^{\circ} \mathrm{N}, 30.2^{\circ} \mathrm{E}$ & $550-770$ & -5 & +17 & $\begin{array}{c}\text { northern } \\
\text { forest-steppe }\end{array}$ & wet-mesic & Argiudolls \\
\hline Kherson & $46.6^{\circ} \mathrm{N}, 32.6^{\circ} \mathrm{E}$ & $315-350$ & 0 & +22 & $\begin{array}{l}\text { southern } \\
\text { steppe }\end{array}$ & dry-thermic & Calciustolls \\
\hline Astana & $51.3^{\circ} \mathrm{N}, 71.1^{\circ} \mathrm{E}$ & $300-350$ & -18 & +19 & $\begin{array}{l}\text { northern } \\
\text { steppe }\end{array}$ & dry-frigid & Haplustolls \\
\hline
\end{tabular}

Table 12. Soil Types and Climatic Characteristics of the Study Sites

\subsection{Soil organic $\mathrm{C}$ and total $\mathrm{N}$ in different climatic zones}

The highest amount of soil organic carbon (SOC) and total nitrogen (TN) was observed in wet-frigid (Kharkov) region, 26.8 and $2.50 \mathrm{~g} \mathrm{~kg}^{-1}$ soil, respectively, and the lowest in dry-mesic (Kherson) region with 15.3 and $1.24 \mathrm{~g} \mathrm{~kg}^{-1}$ soil, respectively (Table 13). This is mainly due to the inherently higher humus content in comparison with other studied soils. These results agree with previously reported studies where the stock of SOC was generally greater in colder and wetter compared to hotter and drier climates [28, 84]. In our study the TN content was significantly higher in frigid (Kharkov and Astana) than in mesic and thermic (Uman and Kherson) regions. Higher amounts of precipitation generally lead to a higher plant biomass production and organic C input [e.g. 15]. In addition, lower temperatures, especially in winter when it falls below a threshold for biological activity, limits decomposition of SOM resulting in accumulation over time [84]. 
Lack of water in the dry-frigid (Astana) region retarded mineralization of plant residues [8] while low winter temperatures conserved plant residues that were partially mineralized when the temperature was favorable, partially immobilized and partially accumulated as a labile organic matter [85].

In wet-mesicUman, the relative temperature sensitivity of decomposition was greater than the net primary productivity [3], where the higher amount of precipitation naturally produced a greater plant biomass that was quickly decomposed due to favorable temperature and moisture conditions. Dry and hot condition in Kherson suppressed the production of plant biomass and limited accumulation of SOM.

\begin{tabular}{|c|c|c|c|c|c|c|c|c|}
\hline \multirow[t]{2}{*}{$\begin{array}{c}\text { Soil type and hydrothermal } \\
\text { regime }\end{array}$} & Total $\mathbf{N}$ & Organic C & $\mathrm{C} / \mathrm{N}$ & $\mathrm{pH}$ & $\mathrm{CaCO}_{3}$ & $\begin{array}{c}\text { Sand } \\
(200-20 \mu \\
\text { m) }\end{array}$ & $\begin{array}{c}\text { Silt } \\
(20-2 \mu \mathrm{m})\end{array}$ & \multirow[t]{2}{*}{$\begin{array}{l}\text { Clay } \\
(<2 \mu \mathrm{m})\end{array}$} \\
\hline & \multicolumn{2}{|c|}{$\mathbf{g ~ k g}^{-1}$ soil } & & & $\%$ & & $\%$ & \\
\hline Hapludolls; Wet-frigid $(n=24)$ & 2.50 & 26.8 & 11 & 6.3 & 0 & 20.4 & 37.5 & 42.1 \\
\hline Argiudol/s; Wet-mesic $(n=24)$ & 1.70 & 20.5 & 12 & 5.6 & 0 & 22.9 & 37.7 & 39.4 \\
\hline Calciustolls; Dry-thermic $(n=12)$ & 1.24 & 15.3 & 12 & 7.5 & 5.5 & 43.4 & 26.9 & 29.7 \\
\hline Haplustolls; Dry-frigid $(n=24)$ & 2.29 & 20.0 & 9 & 8.2 & 1.6 & 25.6 & 30.6 & 43.8 \\
\hline
\end{tabular}

Table 13. General properties of different types of Mollisols from different

\subsection{Labile $C$ fractions of soil organic matter from Mollisols in different climatic zones}

\subsubsection{Potentially mineralizable $C$ and rate constant $k$ from Mollisols in different climatic zones}

Drier regions accumulated a higher amount of potentially mineralizable carbon (PMC) that is presented as $\mathrm{C}_{0}$ in fitting curves (dry-thermic and dry-frigid, 1225 and $1222 \mathrm{mg} \mathrm{kg}^{-1}$ soil, respectively) than of wetter regions (wet-frigid and wet-mesic, 754 and $1091 \mathrm{mg} \mathrm{kg}^{-1}$ soil, respectively) (Fig. 11). Corresponding rate constant $(k)$ followed a similar trend as PMC ( $k$ value of 0.031 and 0.026 in dry-thermic and dry-frigid, respectively; 0.013 and 0.021 in wetfrigid and wet-mesic, respectively). The shape of the fitting curve of Kharkov (wet-frigid) soil greatly differed from others by being the lowest, i.e. reflecting the least amount of mineralized C, and the straightest, i.e. corresponding with the slowest rate of decomposition. On the other extreme, Kherson (dry-thermic) and Astana (dry-frigid) soils showed the highest and the most curved shapes of the fitting curves that reflect the greater amount of mineralized $\mathrm{C}$ and faster decomposition rate in 70 days of incubation.

Moisture was the main factor influencing the amounts of soil labile C. In wetter regions (Kharkov and Uman) microbial respiration is always higher [66], and more organic substrate was utilized than in drier regions. In contrast, soil microorganisms from drier regions 
(Astana and Kherson) experienced moisture deficiency and were unable to use the existing available organic substrate. Consequently, when microbial activity was not limited by moisture during the laboratory incubation there was enough energy substrate to promote a high respiration rate. Additionally, in dry conditions lethal effects contributed "dead biomass" to the organic substrate pool $[66,86,87]$. This easily available substrate was rapidly taken up and utilized by surviving soil microorganisms, thus contributing to the increased soil respiration observed when soils from dry regions were moistened [66]. Severe moisture conditions in Astana and Kherson, firstly, enhanced turnover of $\mathrm{MB}$ and condensation of microbial products, thus increasing the amount of soluble C [60], and secondly, caused disruption of soil aggregates that resulted in the liberation of protected organic C [88].

Dry-mesic, Kharkov

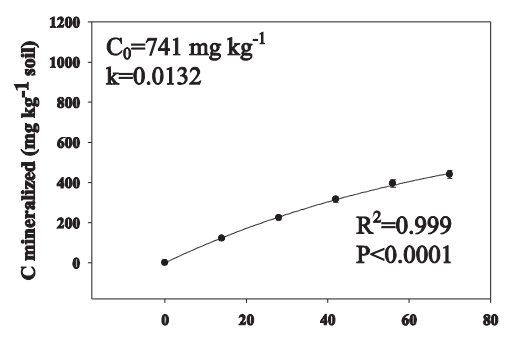

Dry-thermic, Kherson

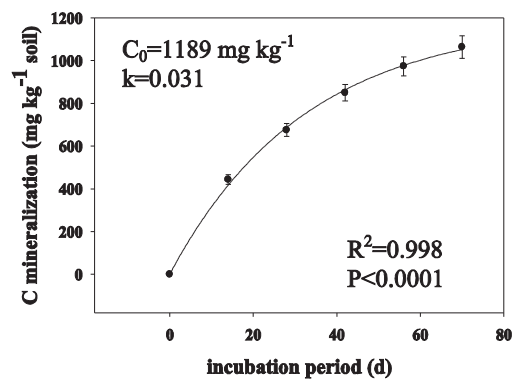

Wet-mesic, Uman

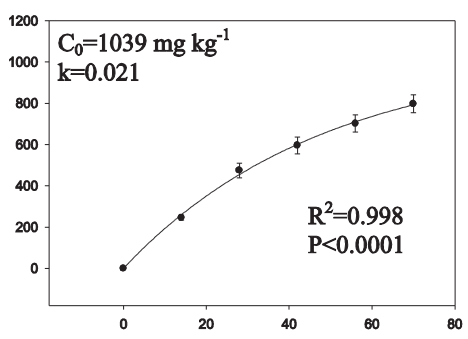

Dry-frigid, Astana

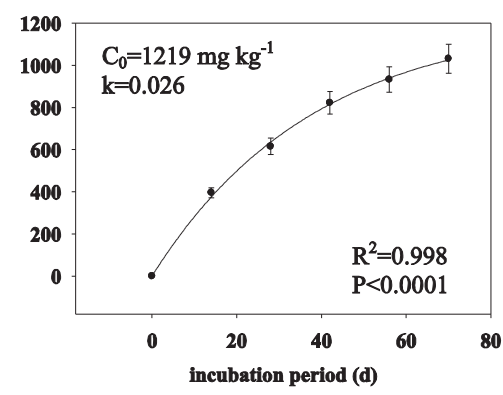

Figure 11. Fitting curves of $C$ mineralization in soils from different climatic regions as described with the first order kinetic model $\left(C \mathrm{~min}=\mathrm{C}_{0}\left(1-\mathrm{e}^{-\mathrm{kt}}\right)\right.$, where, $\mathrm{Cmin}$ is a mineralized $\mathrm{C}$ at time $t, \mathrm{C}_{0}$ is a potentially mineralizable $C$ (PMC), $\mathrm{k}$ is a mineralization rate constant) 
Site variation in Kharkov and Uman were not significant (Figure 12). However, dry regions (Kherson and Astana) showed the biggest variation in the amount of potentially mineralizable C (PMC) and $k$ values within the site. This indicates that SOM of dry regions are more sensitive to the imposed agronomic treatments than wetter regions. As discussed in previous sections, in drier regions the microbial activity is suppressed by lack of water. Then, when the water limitation is excluded the flash of mineralization take a place, where rapidly growing microorganisms compete for the $\mathrm{N}$ thus involving the more stable SOM into the mineralization process. Therefore, the vulnerability of SOM in drier regions should be considered when designing the agronomic treatments.

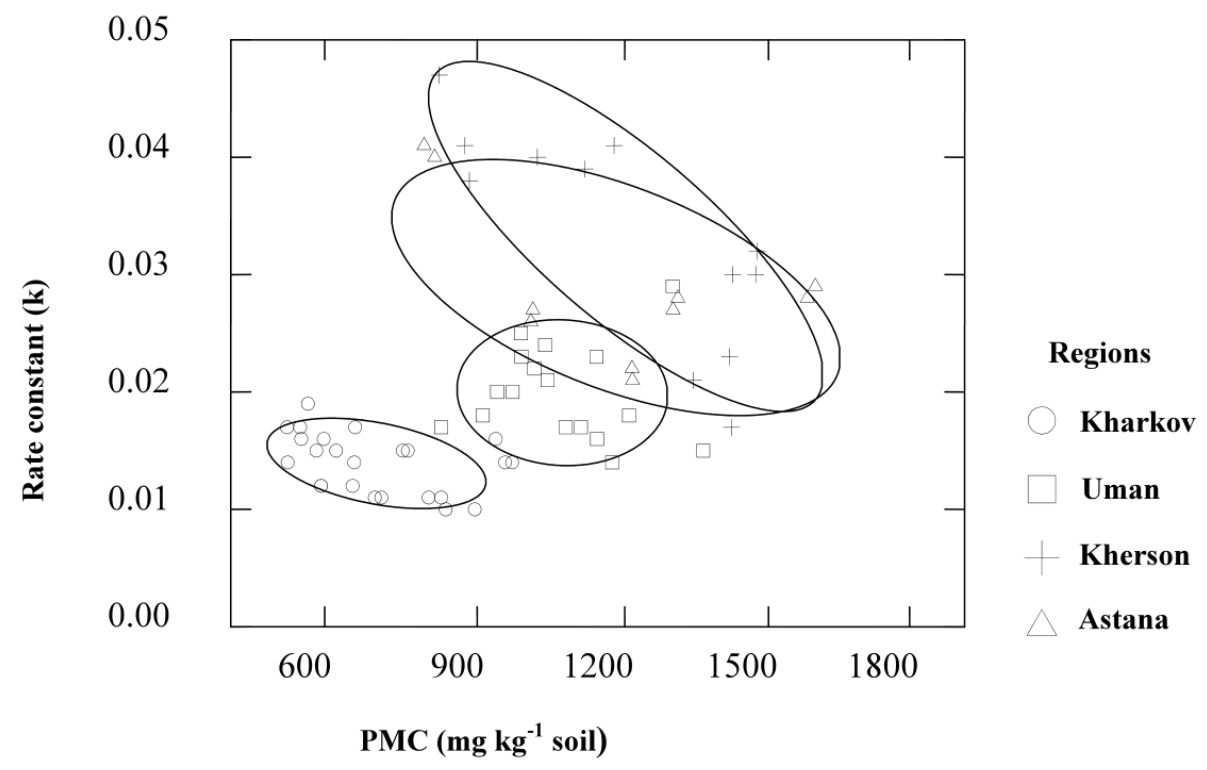

Figure 12. Scatter-plot of mineralized $C$ and decomposition rate constant $(k)$ in Mollisols from different climatic regions

\subsection{2. "Light" fraction organic matter (LF-C) from Mollisols in different climatic zones}

The highest amount of "light" fraction carbon (LFC) was observed in the dry-thermic region (1687 $\mathrm{mg} \mathrm{kg}^{-1}$ soil, Kherson), followed by the dry-frigid region (1436 mg kg-1 soil, Astana), and the least amount of LFC was observed in wet regions (1180 and $1105 \mathrm{mg} \mathrm{kg-1}$ soil in Kharkov and Uman, respectively) (Table 14). Obviously, drier conditions in Kherson and Astana retarded decomposition of SOM, contributing to accumulation of LFC. Generally, distribution of LFC among sites was well correlated with PMC $\left(\mathrm{r}^{2}=0.619\right)$. The amount of LFC was more affected by precipitation rather than by temperature. These results correspond to studies of, for example, $[77,78]$ who reported that decomposition of SOM during 
the period of favourable soil temperature is inhibited by lack of water. In wetter Kharkov and Uman, favorable moisture and temperatures during vegetation season promoted mineralization of "light fraction" OM resulting in less accumulation of LFC.

\begin{tabular}{ccccccc}
\hline \multirow{2}{*}{ Site } & \multicolumn{2}{c}{ MBC } & \multicolumn{2}{c}{ PMC } & \multicolumn{2}{c}{ LFC } \\
\cline { 2 - 7 } & $\mathbf{m g} / \mathbf{k g}$ & \% of SOM & $\mathbf{m g} / \mathbf{k g}$ & $\%$ of SOM & $\mathbf{m g} / \mathbf{k g}$ & $\%$ of SOM \\
\hline Wet-frigid $(\mathrm{n}=24)$ & $203 \pm 18$ & 0.80 & $754 \pm 39$ & 3.00 & $1180 \pm 31$ & 4.65 \\
\hline Wet-mesic $(\mathrm{n}=24)$ & $206 \pm 16$ & 1.00 & $1091 \pm 34$ & 5.10 & $1106 \pm 49$ & 5.39 \\
\hline Dry-thermic $(\mathrm{n}=12)$ & $281 \pm 31$ & 1.84 & $1225 \pm 56$ & 8.00 & $1687 \pm 67$ & 11.03 \\
\hline Dry-frigid $(\mathrm{n}=24)$ & $309 \pm 36$ & 1.54 & $1222 \pm 50$ & 6.16 & $1436 \pm 58$ & 7.18 \\
\hline
\end{tabular}

Table 14. Labile Carbon Fractions in different types of Mollisols

\subsubsection{Microbial biomass carbon in Mollisols from different climatic zones}

Microbial biomass C (MBC) was significantly higher under drier (281 and $309 \mathrm{mg} \mathrm{kg}^{-1}$ soil in Kherson and Astana, respectively) comparing with wetter (203 and $206 \mathrm{mg} \mathrm{kg}^{-1}$ soil in Kharkov and Uman, respectively) regions (Table 14). The effect of temperature on microbial biomass was not clearly observed in this study.

As shown by data of LFC, drier regions accumulated a greater amount of organic substrate that favoured accumulation of microbial biomass due to its availability as energy source. However, because microbial activity and survival are in direct physiological dependence on available water [87], the moisture deficiency during the summer period retarded microbial activity and caused death of moisture-sensitive microorganisms. After remoistening of the soils, the inhibition of microbial activity by dry conditions was reactivated and the available necromass was rapidly metabolized by soil microorganisms leading to the higher accumulation of $\mathrm{MBC}$ in drier regions.

Changes in the relative contribution of bacteria and fungi to soil respiration occur as soil dries [66] Kharkov and Uman soils normally undergo less severe fluctuations in water potential that Kherson and Astana. $[89,90]$ have shown that bacterial activity is largely restricted to water films in soil in contrast to fungi activity. Hyphae extension occurs at much lower potentials allowing fungi to bridge air-filled pores and actively explore for nutrients [91].

\subsubsection{Relationship between soil organic matter and clay content}

The inert carbon is strongly correlated with clay content, while most changes in both carbon and nitrogen occur in the readily decomposable fraction [92]. Firstly, clay minerals can absorb large organic molecules directly, reducing their availability to decomposition. Secondly, organic material may be located in pores too small for microorganisms to enter [93-97). 
In this study, clay content was highest in Kharkov and Astana regions (43.1\% and $48.8 \%$, respectively) versus Uman and Kherson (39.4\% and 29.7\%, respectively) (Table 15). It is reasonable to conclude that higher clay content and plant biomass production in Kharkov maintained higher SOM. [92] reported that inert carbon was strongly correlated with clay content, while most changes in both carbon and nitrogen occur in the readily decomposable fraction. [98] determined that "light fraction" (LF) of fine silt and coarse clay was more humified and more aromatic than other LF, concluding that LF represents a continuum of undecomposed to highly humified materials. Sites with higher silt fraction $(2-0.2 \mu \mathrm{m})$ that are Kharkov and Uman (37.5\% and $37.7 \%$, respectively) might form organo-mineral complexes with large molecules of LF, where those mineral-associated LF probably were not retrieved from these soils during the separation procedure, whereas, Kherson and Astana contained less silt fraction $(26.9 \%$ and $26.6 \%$, respectively) that could entrap LF, resulting in higher LFOM in these soils.

\begin{tabular}{ccccc}
\hline Regions & Siol organic carbon & Sand & Silt & Clay \\
\cline { 2 - 5 } & $\mathbf{g ~ \mathbf { ~ g ~ } ^ { - 1 } \text { soil }}$ & $\mathbf{2 0 0 - 2 0 \mu \mathbf { m }}$ & $\mathbf{2 0 - 2} \boldsymbol{\mu m}$ & $<\mathbf{2 \mu \mathbf { m }}$ \\
\hline Kharkov $(n=24)$ & 25.4 & 20.4 & 37.5 & 42.1 \\
\hline Uman $(n=18)$ & 20.5 & 22.9 & 37.7 & 39.4 \\
\hline Kherson $(n=12)$ & 15.3 & 43.4 & 26.9 & 29.7 \\
\hline Astana $(n=24)$ & 20.0 & 25.6 & 30.6 & 43.8 \\
\hline
\end{tabular}

Table 15. Granulometric composition of studied soil from different climatic regions

However, although Astana soil showed the highest content of clay the SOM in this soil was less than in Kharkov. This is explained by the lack of water in dry-frigid Astana that produces less plant biomass, and inhibits mineralization processes contributing to the accumulation of labile OM, which explains higher PMC content in this soil. Also, organic compounds adsorbed to surfaces of clay particles become exposed to microbial attack after disruption of aggregates due to severe dry-wet conditions on soil in Astana [34]. The lowest clay content $(29.7 \%)$ and lack of water in Kherson can explain the lowest SOM content in this soil, since the dry-thermic conditions don't contribute to high plant biomass.

\subsubsection{General discussion of effect of moisture and temperature on SOM in Mollisols}

Total SOM among the four regions was distributed as follows: dry-thermic $<$ dry-frigid $\leq$ wet-mesic < wet-frigid. While the labile OM distributed oppositely, as follows: dry-thermic $\geq$ dry-frigid $>$ wet-mesic $>$ wet-frigid. In Figure 13 the proportions of labile and stable carbon in the studied regions is presented. The highest amount of stable $C$ and the least amount of labile $C$ was found in wet-frigid (Kharkov) region, while the least amount of stable and the greatest amount of labile $\mathrm{C}$ was found in dry-thermic (Kherson) region. Because wet-frigid (Kharkov) region maintained the highest amount of total SOC and the least amount of easily 
mineralizable organic matter (PMC), the suggestion is: in wet-frigid region transformation of organic substrates into more stable humified forms of OM has taken place more actively

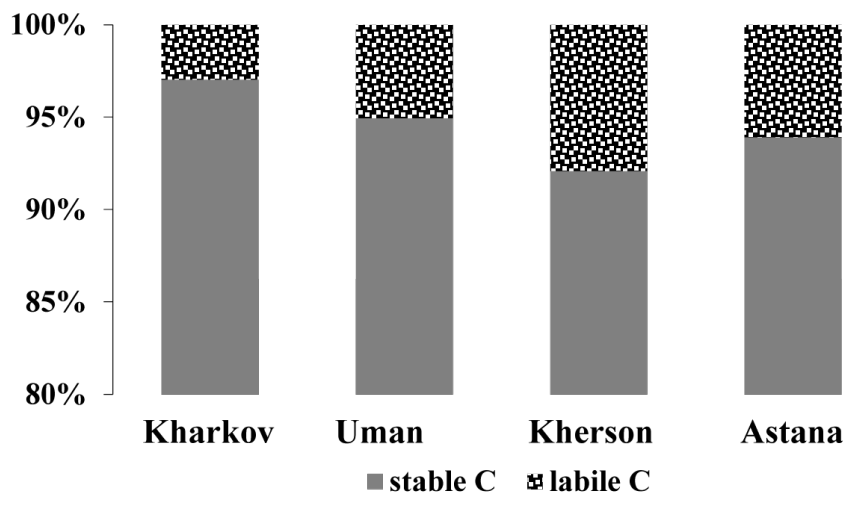

Figure 13. Distribution of labile and stable $\mathrm{C}$ in different Mollisols from four studied sites

Higher precipitation contributed stronger to the amount of total SOM, while plant biomass production under drier conditions in a lesser degree was subjected to decomposition due to moisture deficiency, thus contributing to the amount of labile SOM. The amount of $\mathrm{C}$ reflecting the labile fraction increases with increasing temperature, while the amount of recalcitrant $\mathrm{C}$ more controlled by low temperature.

Readily decomposable substrates were also found to originate partially from non-living SOM $[62,63]$. This source of non-biomass substrate may become available by aggregate disruption, litter defragmentation and substrate desorption, and redistribution of water, oxygen, substrate and microorganisms resulting from drying and rewetting of soil $[62,63,65$, $99,100]$. Soil drying and rewetting promotes the turnover of carbon derived from added plant material $[62,63]$. Drier condition causes more disruptions of entrapped or stabilized organic matter when the soil is rewetted. Also, higher respiration in the soils exposed to wet-dry cycles may have been due to utilization of organic substrate that were gradually built up due to limited microbial activity when the soil was air-dried [66].

\section{Carbon to nitrogen ratio ( $\mathrm{C}$ to $\mathrm{N})$ of plant residues}

Quite precise integral index of quality of organic matter, from which the intensity of its decomposition depends, appears the ratio of carbon to nitrogen (C: N). Plant remainders with the wide ratio $\mathrm{C}$ to $\mathrm{N}$ do not ensure the sufficiency of nitrogen for the metabolism of microorganisms at their high activity. When the rapidly metabolized substrata (carbohydrates) are depleted, the limitation of nourishment is changed from nitrogen to carbon.

"Critical" C to N ratio, which characterizes accessibility to the microorganisms of the nutrients contained in the remainders, and their influence on the soil fertility, varies from 15 to 
30 depending on the pool of mineral nitrogen in the soil, the quality of organic matter, duration of their of the decomposition. With an increase in the value indicated the processes of decomposition slow down and the immobilization of nitrogen occurs. With the smaller C:N values the intensive mineralization of plant litter occurs as a result of the invigoration of the activities of the microflora. The studies on the Mollisols showed that among the studied crops the maximum speed of decomposition was for the postharvest remainders of alfalfa and pea, which have the narrowest $\mathrm{C}$ to $\mathrm{N}$ ratio, 19,4 and 26,8 respectively. The percentage of the decomposition of pea in the first two months was 47,2 , in seven months - 52,8, in a year $-82,4$. The lowest intensity of decomposition process was recorded under the residues of winter wheat. The changes of the ratio in the crop residues occurred in essence due to the content of nitrogen, which increased more rapidly than carbon. In more easily decomposing plant biomass the proteins of microbial synthesis are formed more rapidly thus contributing to the development of humification processes.

During the decomposition process, $55-70 \%$ of the carbon in the residue is released to the atmosphere as $\mathrm{CO}_{2}, 5-15 \%$ of the $\mathrm{C}$ is incorporated into the soil microbial biomass, and the remaining $15-40 \%$ of $C$ is partially stabilized as new soil humus [101, 102]. Crop residues contain lignin, which is resistant to decomposition and becomes a substrate for soil humus formation. The more lignin in a residue type the slower the decomposition and the larger its contribution to the soil humus formation. Older, mature residues will tend to have more lignin content than young, non-mature residue from the same crop. The simple sugars, amino acids, polysaccharides, proteins, and lipids decompose first in the decomposition process.

Nitrogen $(\mathrm{N})$ is necessary for the decomposition process. The less $\mathrm{N}$ the residue contains relative to the $\mathrm{C}$, the slower the decomposition rate. If the residue $\mathrm{N}$ content is low, or the $\mathrm{C}: \mathrm{N}$ ratio high, the decomposition process will require the input of $\mathrm{N}$ from either available soil inorganic $\mathrm{N}$ or fertilizer. Generally, residues with $\mathrm{N}$ concentrations less than $1.5 \%$ or C:N ratios greater than 30 will require $\mathrm{N}$ from sources outside the residue itself; it will immobilize soil $\mathrm{N}$ [107]. Residues with greater $\mathrm{N}$ concentration or lower C: $\mathrm{N}$ ratios, as is frequently the case with legume residues or non-mature residues, tend to decompose at a more rapid rate and will release or mineralize $\mathrm{N}$. The actual decomposition rate will depend on $\mathrm{N}$ content and chemical composition of the residue and the environmental conditions such as soil moisture and temperature. Crop residues such as corn and wheat residue have large C:N ratios and soil $\mathrm{N}$ will be immobilized during the decomposition process. However, mineralization of $\mathrm{N}$ will generally start to occur after $50-60 \%$ of the residue has been decomposed [108] when enough $\mathrm{C}$ has been volatilized as $\mathrm{CO}_{2}$ and $\mathrm{N}$ immobilized such that the remaining residue C: $\mathrm{N}$ ratio is below 30. Nitrogen immobilization reduces $\mathrm{N}$ availability to the growing crop and $\mathrm{N}$ mineralization increases $\mathrm{N}$ availability. The addition of a large quantity of oxidizable carbon from litter with the content of $\mathrm{N}$ less than 1,5\% creates microbiological demand on $\mathrm{N}$, thus immobilizing $\mathrm{N}$ of plant litter and inorganic $\mathrm{N}$ of soil. Effect of substrate composition on decomposition is described by $\mathrm{C}$ to $\mathrm{N}$ ration, based on the fact that $\mathrm{N}$ is the most limiting factor for decomposition. With ongoing decomposition the $\mathrm{C}$ to $\mathrm{N}$ ratio is narrowing thus the carbon energy supply is decreasing. 


\section{Conclusions}

The studies confirm that the transformations of SOM are generally concentrated within labile pool. The process of mineralization of organic matter in soil is controlled predominantly, by the climatic factors (moisture and temperature) and plant litter quality (mainly by content of $\mathrm{N}$ ), then by land management.

In the $21^{\text {st }}$ century the mineral fertilizers became determinant for obtaining contented yield of agricultural crops. However, the application of only mineral fertilizer might lead to accelerated mineralization of the more stable soil organic matter. Instead, application of manure in combination with mineral fertilizer $[38,56-58,103]$ might contribute in both obtaining the content crop yield and sustaining the soil fertility.

Yearly input of plant residue in less fallowed rotation system built up more labile OM, especially readily decomposable $\mathrm{C}$, whereas frequent fallowing depletes SOM via accelerated mineralization. Therefore, in the semi-arid regions the inclusion of fallow in wheat monoculture every 6 years is the most appropriate farming system in terms of sustainability in both grain production and soil fertility.

Higher precipitation produced higher plant biomass contributing to the amount of SOM with further decomposition upon temperatures and soil texture. While less plant biomass production in drier regions in a lesser degree was subjected to decomposition due to moisture deficiency, thus contributing to the amount of labile SOM. Because wet-frigid region maintained the highest amount of total organic carbon and the least amount of easily mineralizable organic matter (PMC), transformation of organic substrates into more stable humified forms of organic matter might have taken place more actively in this region.

Understanding the processes of SOM changes under the impact of land management and different moisture and temperature regimes would greatly contribute to most ecological problem of $\mathrm{C}$ sequestration supplying with valuable information about land use management.

\section{Author details}

Elmira Saljnikov ${ }^{1}$, Dragan Cakmak $^{1}$ and Saule Rahimgalieva ${ }^{2}$

*Address all correspondence to: elmirasal@mail.ru

1 Institute of Soil Science, Belgrade, Serbia

2 West-Kazakhstan Agrarian-Technical University named after Zhangir-Khan, Uralsk, Kazakhstan 


\section{References}

[1] Sollins, P., Homann, P. and Caldwell, B.A. 1996. Stabilization and destabilization of soil organic matter - mechanisms and controls. Geoderma 74: 65-105

[2] Six J, Bossuyt H, De Gryze S, Denef K. 2004. A history of research on the link between (micro) aggregates, soil biota, and soil organic matter dynamics. Soil Till Res 79:7-31

[3] Baldock, J.A., Nelson, P.N, 2000. Soil organic matter. In Sumner, M.E., (Ed.), Handbook of Soil Science. CRC Press, Boca Raton, pp. B25-B84

[4] Post, W.M., Emmanuel, W.R., Zinke, P.J. and Stangenberger, A.G., 1982. Soil carbon pools and world life zones. Nature 298: 156-159.

[5] Saljnikov E., Cakmak, D., Kostic L., and Maksimovic, S. 2009. Labile fractions of soil organic carbon in Mollisols from different climatic regions. Agrochimica. Vol. LIII, 6

[6] Campbell, C.A. 1978. Soil organic carbon, nitrogen, and fertility. In: Schnitzer M., Khan, S.U., (Eds.) Soil organic matter. Elsevier, New York, pp 173-271

[7] Beiderbeck, V.O., Campbell, C.A. and Zentner, R.P., 1984. Effect of crop rotation and fertilization on some biological properties of a loam in southwestern Saskatchewan. Can. J. Soil Sci. 64: 355-367.

[8] Saljnikov-Karbozova, E., Funakawa, S., Akhmetov, K., and Kosaki, T. 2004. Soil organic matter status of Mollisols soil in North Kazakhstan: effects of summer fallow. Soil Biol.Biochem. 36: 1373-1381

[9] Campbell, C.A. and Souster, W., 1982. Loss of organic matter and potentially mineralizable nitrogen from Saskatchewan soils due to cropping. Can. J. Soil Sci. 62: 651-656.

[10] Rasmussen, P.E., Allmaras, R.R., Rohde, R.R. andRoager, N.C., 1980. Crop residue influences on soil carbon and nitrogen in a wheat-fallow system. Soil Sci. Soc. Am. J. 44: 596-600

[11] Saljnikov E., Hospodarenko H., Funakawa S and Kosaki T. 2005. Effect of fertilization and manure application on nitrogen mineralization potentials in Ukraine. Zemljiste i biljka, vol.54, 3: 221-230.

[12] Couteaux, M.M., Bottner, P. And Berg, B. 1995. Litter decomposition, climate and litter quality. Tree 10: 63-66.

[13] Zou, X.M.; H.H. Ruan, Y. Fu, X.D. Yang and L.Q. Sha.Estimating soil labile organic carbon and potential turnover rates using a sequential fumigation-incubation procedure. Soil Biol. Biochem.37, 10, 2005, pp. 1923-1928 
[14] Christensen, B.T. 1986. Barley straw decomposition under field conditions: Effect of placement and initial nitrogen content on weight loss and nitrogen dynamics. Soil Biol. Biochem. 18: 523-529

[15] Sparling, G.P., 1992. Ratio of microbial biomass to soil organic carbon as a sensitive indicator of changes in soil organic matter. Aust. J. Soil Res. 30: 195-207

[16] Franzluebbers, K., Weaver, R.W., Juo, A.S.R. and Franzluebbers, A.J., 1994. Carbon and nitrogen mineralization from cowpea plant parts decomposing in moist and in repeatedly dried and rewetted soil. Soil Biol. Biochem. 26: 1379-1387.

[17] Gregorich, E. G. and Janzen, H.H. 1996. Storage of soil carbon in the light fraction and macroorganic matter. P. 167-190. In M.R. Carter and B.A. Stewart (ed.) Structure and organic matter storage in agricultural soils. CRC press, Boca Raton, FL

[18] Keeney, D.R. 1982. Nitrogen-availability indices. In A.L. Page et al., Eds. Methods of Soil Analysis. Part 2, 2nd ed. Chemical and Microbiological Properties, Agronomy 9. SSSA and ASA, Madison, WI, pp. 711-733

[19] Christensen, B.T., 1996. Carbon in primary and secondary organo-mineral complexes. Advances in Soil Science 24, 97-165.

[20] Elliott, E.T., Paustain, K., Frey, S.D., 1996a. Modeling the measurable or measuring the modelable: A hierarchical approach to isolating meaningful soil organic matter. In D.S.

[21] Elliot, L.F., Lynch, J.M., and Papendick, R.I. 1996b. The microbial component of soil quality. In G. Stotsky and J.M.Bollag, Eds. Soil Biochemistry, Vol. 9. Marcel Dekker, New York, NY, pp. 1-20.

[22] Breland, T.A. and Eltun, R., 1999. Soil microbial biomass and mineralization of carbon and nitrogen in ecological, integrated and conventional forage and arable cropping systems. Biol. Fert. Soils, 30: 193-201.

[23] Nelson, D.W. and Sommers, L.E. 1996. Total carbon, organic carbon, and organic matter. In Page, A.L., Miller, R.H., Keeney, D.R. (eds.) Methods of Soil Analysis, Part 3, SSSA, Madison, WI.

[24] SPSS Inc., SYSTAT 1998. version 8.0, Statistics, Chicago, IL.

[25] SPSS Inc., 2007. Sigma Plot version 6.0, Programming guide, Chicago, IL.

[26] Jalil, A., Campbell, C.A., Schoenau, J., Henry, J.L., Jame, Y.W., and Lafond, G.P. 1996. Assessment of two chemical extraction methods as indices of available nitrogen. Soil Sci. Soc. Am. J. 60: 1954-1960.

[27] Picone, L.I., Cabrera, M.L., and Franzluebbers, A.J. 2002. A rapid method to estimate potentially mineralizable nitrogen in soil. Soil Sci. Soc. Am. J. 66: 1843-1847.

[28] Jenkinson, D.S. 1988. Soil organic matter and its dynamics.. In A. Wild (ed.) Soil Condition and Plant Growth. Longman, New York. pp. 564-607. 
[29] Smith, J.L. and Paul, E.A. 1990. The significance of soil microbial biomass estimations. In J.-M. Bollag and G. Stotzky, Eds. Soil Biochemistry, Vol. 6. Marcel Dekker, New York, NY, pp. 357-396

[30] Brookes, P.C., Ocio, J.A., and Wu, J. 1990. The soil microbial biomass: its measurement, properties and role in soil nitrogen and carbon dynamics following substrate incorporation. Soil Microorganisms. 35: 39-51

[31] Powlson, D.S., Brookes, P.C., and Christensen, B.T. 1987. Measurement of soil microbial biomass provides an early indication of changes in total soil organic matter due to straw incorporation. Soil Biol. Biochem. 19: 159-164

[32] Spedding T.A., Hamel C., Mehuys G.R., Madramootoo C.A. (2004): Soil microbial dynamics in maize-growing soil under different tillage and residue management systems. Soil Biology and Biochemistry, 36: 499-512.

[33] Herna'ndez-Herna'ndez, R.M.andLo' pez-Herna'ndez,D. 2002. Microbial biomass, mineral nitrogen and carbon content in savanna soil aggregates under conventional and no-tillage. Soil Biol. Biochem. 34: 1563-1570.

[34] Jenkinson D.S. and Powlson D.S. 1976. The effects of biocidal treatment on metabolism in soil: V. A method for measuring soil biomass. Soil Biol. Biochem. 8: 209-213

[35] Sparling, G.P and West, A. W. 1998. A direct extraction method to estimate soil microbial biomass $\mathrm{C}$ : calibration in situ using microbial respiration and ${ }^{14} \mathrm{C}$ labeled cells. Soil Biol. Biochem. 20: 337-343

[36] Janzen, H.H., Campbell, C.A, Brandt, S.A., LaFond, G.P. and L.Townley-Smith. 1992. Light-Fraction Organic Matter in Soils from Long-Term Crop Rotations. Soil Sci.Soc.Am.J. 56: 1799-1806.

[37] Nosko, B.S., 1987. Changes of humus status of Typical Chernozem upon fertilization. Pochvovedenie, 5: 26-31 (in Russian)

[38] Chesnyak, G. Ya., 1981. Changes of humus quantity and quality and the ways of providing of positive humus balance in Typical Chernozems of Ukraine under intensive agricultural use. In publications of VI Meeting of Soil Science Society of USSR, V.2, pp.42-43. (in Russian).

[39] Aleksandrova, L.N., 1980. Soil organic matter and its transformation. Nauka, Moscow, p. 288. (in Russian).

[40] Kononova, M.M., 1956. Humus of the main soils of SSSR, its nature and ways of forming. Pochvovedenie, 3: 18-30. (in Russian).

[41] Mamontov, V.T., 1971. Effect of agricultural use on the agronomical properties of thick Chernozem in west forest-steppes of Ukraine. In doctoral thesis of the author, p. 234. (in Russian).

[42] Ilyaletdinov, A., 1988. Microbiological conversion of nitrogen compounds in the soil. Nauka, Moscow, 119-154pp. 
[43] Ferguson, W.S., Gorby, B.J., 1971. Effect of various periods of seed-down to alfalfa and bromegrass on soil nitrogen. Canadian Journal of Soil Science 51. 65-73.

[44] Clarke, A.L., Russell, J.S., 1977. Crop sequential practices. In: J.S. Russell, E.L. Greacen, (Eds), Soil Factors in Crop Production in a Semi-arid Environment. University of Queensland Press, St. Lucia, pp. 279-300.

[45] Dormaar, J.F., 1983. Chemical properties of soil and water-stable aggregates after sixty-seven years of cropping to spring wheat. Plant and Soil 75, 51-61.

[46] Bird, M.I., Chivas, A.R., Head J., 1996. A latitudinal gradient in carbon turnover times in forest soils. Nature 381, 143-146.

[47] Amelung W., Flach, K.W., Zech W., 1998. Climatic effects on soil organic matter composition in the Great Plains. Soil Science Society of America Journal 61, 115-123.

[48] Christensen, B.T., 1992. Physical fractionation of soil and organic matter in primary particles and density separates. Advances in Agriculture 20, 2-90.

[49] Trumbore, S.E., Chadwick, O.A., Amundson R., 1996. Rapid exchange between soil carbon and atmospheric carbon dioxide driven by temperature change. Science 272 , 393-396.

[50] Collins, H.P., Rasmussen, P.E., Douglas, C.L., 1992. Crop rotation and residue management effects on soil carbon and microbial dynamics. Soil Science Society of America Journal 56, 783-788.

[51] Campbell, C.A., Zentner, R.P., 1993. Soil organic matter as influenced by crop rotations and fertilization. Soil Science Society of America Journal 57, 1034-1040.

[52] Biederbeck, V.O., Janzen, H.H., Campbell, C.A., Zentner, R.P., 1994. Labile soil organic matter as influence by cropping practices in an arid environment. Soil Biology \& Biochemistry 12, 1647-1656.

[53] Janzen, H.H., 1987. Soil organic matter characteristics after long-term cropping to various spring wheat rotations. Canadian Journal of Soil Science 67, 845-856.

[54] Cheng, HH, \& Kimble, JM. 2001. Characterization of soil organic carbon pools. In R. Lal, JM Kimble, RF Follett, \& BA Stewart (Eds.), Assessment methods for Soil Carbon. CRC/Lewis Press, Boca Raton, FL, 676 pp.

[55] Singh J.S. and Gupta S.R. 1977. Plant decomposition and soil respiration in terrestrial ecosystems. Bot. Rev. 43:449-528.

[56] Chesnyak, G. Ya., 1986. Modification to the determination of coefficient of humification of plant residues in Typical Chernozems of forest-steppe Ukraine in grain-beet crop rotation. Agrochemistry and soil science, Kiev, 49: 77-92. (in Russian).

[57] Voroney, R.P., 1988. Loss of organic matter in Ontario soils. Highlights. V.11, No.3, pp. 25-29. 
[58] Pare, T., Dinel, H., Moulin, A.P. and Townley-Smith, L., 1999. Organic matter quality and structural stability of a Black Chernozemic soil under different manure and tillage practices. Geoderma 91: 311-326

[59] Kharin, S.V., 1993. Humification and regulation of humus status of different cropping systems in Typical Chernozems of west forest-steppe of Ukraine. PhD thesis, Institute of Soil Science and Agrochemistry after Sokolovski, Kharkov, Ukraine (in Russian).

[60] Lundquist, E.J., Jackson, L.E. and Scow, K.M. 1999. Wet-dry cycles affect dissolved organic carbon in two California agricultural soils. Soil Biol. Biochem. 31: 1031-1038.

[61] Bottner, P., 1985. Response of microbial biomass to alternate moist and dry conditions in a soil incubated with $14 \mathrm{C}$ - and $15 \mathrm{~N}$-labelled plant material. Soil Biol. Biochem. 17: 329-337

[62] Van Gestel, M., Merckx, R. and Vlassak, K., 1993b. Microbial biomass responses to soil drying and rewetting: the fate of fast- and slow-growing microorganisms in soils from different climates. Soil Biol. Biochem. 25: 125-134.

[63] Van Gestel, M., Merckx, R. and Vlassak, K., 1993a. Microbial biomass responses to soil drying and rewetting: the fate of fast- and slow-growing microorganisms in soils from different climates. Soil Biol. Biochem. 25: 109-123.

[64] Pulleman, M. and Tietama, A., 1999. Microbial C and N transformations during drying and rewetting of coniferous forest floor material. Soil Biol. Biochem. 31: 275-285.

[65] Lund, V. and Goksoyr, J., 1980. Effects of water fluctuations on microbial mass and activity in soil. Microbial Ecology 6: 115-123

[66] Orchard, V.A. and Cook, F.J. 1983. Relationship between soil respiration and soil moisture. Soil Biol. Biochem. 15: 447-453.

[67] Kononova, M.M., Pankova, N.A. and Belchikova N.P., 1949. Changes in quality and quantity of soil organic matter under cultivation. Pochvovedenie, 1: 28-37. (in Russian).

[68] Beauchamp, E.G., 1980. Nitrogen from liquid dairy cattle manure for corn. Highlights Agr. Res. In Ontario, V.3, No.4, pp.10-12.

[69] Anderson, D.W., Joug, E de, Verity, G.E. and Gregorich, E.G., 1986. The effect of cultivation on the organic matter of soils of the Canada prairies. Transact. 13 Cong. Int. Soc.Soil Sci., Hamburg, 13-20 Aug., V. 4, SI, S.9, pp.1344-1345.

[70] Van Gestel, M., Ladd, J.N., and Amato, M., 1991. Carbon and nitrogen mineralization from two soils of contrasting texture and microaggregate stability: influence of sequential fumigation, drying and storage. Soil Biol. Biochem. Vol.23, No.4, 313-322

[71] Rubinstein, M.I., 1959. Decomposition rate of organic matter of virgin Chernozem in Northern Kazakhstan during their cultivation. Soviet Soil Science 11: 1332-1335 
[72] Dzhalankuzov, T D. and Redkov, V.V., 1993. Changes in morphological and agrochemical properties of calcareous Southern Chernozems of North Kazakhstan due to long-term cultivation. In: Proceedings of Academy of Sciences of Republic of Kazakhstan, Biology Series 1: 53-58 (in Russian)

[73] Campbell, C.A., Biederbeck, V.O., McConkey, B.G., Curtin, D., Zentner, R.P., 1999. Soil quality-effect of tillage and fallow frequency. Soil organic matter quality as influenced by tillage and fallow frequency in a silt loam in southwestern Saskatchewan. Soil Biology \& Biochemistry 31, 1-7.

[74] Campbell, C.A., Moulin, A.P., Bowren, K.E., Janzen, H.H., Townly-Smith, L., Biederbeck, V.O., 1992. Effect of crop rotation on microbial biomass, specific respiratory activity and mineralizable nitrogen in a Black Chernozemic soil. Canadian Journal of Soil Science 72, 417-427.

[75] Haynes, R.J., 2000. Labile organic matter as an indicator of organic matter quality in arable and pastoral soils in New Zealand. Soil Biology \& Biochemistry 32, 211-219

[76] Gregorich, E.G., Carter, M.R., Angers, D.A., Monreal, C.M., Ellert, B.H., 1994. Towards a minimum data set to access soil organic matter quality in agricultural soils. Canadian Journal of Soil Science 74, 367-385

[77] Shields, J.A. and Paul, E.A. 1973. Decomposition of ${ }^{14}$ C-laballed plant material under field conditions. Can. J. Soil Sci. 53: 297-306, 1973.

[78] Douglas, C.L. Jr., Rickman, R.W., Klepper, B.L., Zuzel, J.F. and Wysocki, D.J. 1992. Agroclimatic zones for dryland winter wheat producing areas of Idaho, Washington, and Oregon. Northwest Science 66: 26-34

[79] Raich, J. W. and C. S. Potter. 1995. Global Patterns of Carbon Dioxide Emissions from Soils. Global Biogeochemical Cycles 9(1)23-36. 10.3334/CDIAC/lue.db1015

[80] Fierer N, B Colman, JP Schimel, RB Jackson. 2006. Predicting the temperature dependence of microbial respiration in soil: A continental-scale analysis Global Biogeochemical Cycles 20, GB3026c

[81] Davidson, E.A., S.E. Trumbore, and R. Amundson. 2000. Biogeochemistry: Soil warming and organic carbon content. Nature. 408:789-790.

[82] Janzen, H.H., 2004. Carbon cycling in earth systems-a soil science perspective. Agriculture, Ecosystems and Environment, 104, 399-417

[83] Soil Taxonomy $2^{\text {nd }}$ ed., 1999. USDA, Washington, DC. pp.555-655.

[84] Franzluebbers, A.J., Haney, R.L., Honeycutt, C.W., Arshad, M.A., Schomberg, H.H. and Hons, F.M. 2001. Climatic influences on active fractions of soil organic matter. Soil Biol.Biochem. 33: 1103-1111

[85] Aleksandrova, L.N. 1972. Study of the humification of plant residues and of the nature of newly formed humic acids. Pochvovedenie 7: 37-45. 
[86] Marumoto, T., Kai, H., Yoshida, T. and Harada T. 1977. Drying effect on mineralization of microbial cell walls as a source of decomposable soil organic matter due to drying. Soil Sci. Plant Nutr. 23: 9-19

[87] Mikha, M.M., Rice, C.W. and Milliken, G.A. 2004. Carbon and nitrogen mineralization as affected by drying and wetting cycles. Soil Biol. Biochem. 37: 339-347

[88] Wu, J. and Brookes, P.C. 2005. The proportional mineralization of microbial biomass and organic matter caused by air-drying and rewetting of a grassland soil. Soil Biol. Biochem. 37: 507-515.

[89] Wong, P.T.W. and Griffin, D.M., 1976a. Bacterial movement at high matric potentials-I. In artificial and natural soils. Soil Biol. Biochem. 8: 215-218.

[90] Wong, P.T.W. and Griffin, D.M., 1976b. Bacterial movement at high matric potentials-II. In fungal colonies. Soil Biol. Biochem. 8: 219-223.

[91] Griffin, D.M., 1969. Soil water in the ecology of fungi. Annual Review of Phytopathology, 7: 289-310

[92] Körschens, M., Weigel, A. and Schulz, E., 1998. Turnover of soil organic matter (SOM) and long-term balances-tools for evaluating sustainable productivity of soils. Z. Pflanzenernähr. Bodenk., 161: 409-424

[93] Juma, N.G., 1993. Interrelationship between soil structure /texture, soil biota/soil organic matter and crop production. Geoderma 57: 3-30

[94] Elliott, E.T., 1986. Aggregate structure and carbon, nitrogen and phosphorous in native and cultivated soils. Soil Sci.Soc. Am. J., 50: 627-633

[95] Gupta, V.V.S.R. and Germida, J.J., 1988. Distribution of microbial biomass and its activity in different soil aggregate size classes as affected by cultivation. Soil Biol. Biochem. 20: 777-786

[96] Amelung, W. and Zech, W., 1996. Organic species in ped surface and core fractions along a climosequence in the prairie, North America. Geoderma 74: 193-206

[97] Gregorich, E.G., Kachanoski, R.G. and Voroney, R.P., 1989. Carbon mineralization in soil size fractions after various amounts of aggregate disruption. Journal of Soil Sci. 40: 649-659

[98] Turchenek, L.W. and Oades, J.M., 1979. Fractionation of organo-mineral complexes by sedimentation and density techniques. Geoderma 21:311-343

[99] Sommers, L.E., Gilmour, C.M., Wildung, R.E. and Beck, S.M., 1981. The effect of water potential on decomposition processes in soil. In: Parr, J.F., Gardner, W.R., Elliot, L.F. (Eds.), Water Potential Relations in Soil Microbiology. Soil Sci. Soc. Am., Madison, pp.97-117. 
[100] Kieft, L.T., Soroker, E. and Firestone, M.K., 1987. Microbial biomass response to a rapid increase in water potential when dry soil is wetted. Soil Biol. Biochem. 19: 119-126.

[101] Jenkinson, D.S. 1971. The Accumulation of Organic Matter in Soil Left Uncultivated. Rothamsted Experimental Station Report for 1970, part 2: 113-137

[102] Stott, D.E., and J.P. Marten, 1989. Organic matter decomposition and retention in arid soils. Arid Soil Res. Rehab. 3:115

[103] Kononova, M.M., 1951. Problems of soil humus and contemporary methods of their study. Moscow, pp.390. (in Russian).

[104] Jenkinson, D.S., Adams, D.E. and Wild A. 1991. Model estimation of CO2 emissions from soil in response to global warming. Nature 351: 304-306

[105] Zak, J.C., M.R. Willig, D.L. Moorhead and H.G. Wildman, 1994.Functional diversity of microbial communities: a quantitative approach, Soil Biol. Biochem. 26, 1101-1108.

[106] Gregorich, E.G. and Janzen, H.H., 2000. Decomposition. In Handbook of Soil Science. Sumner M. E. (Ed.), pp. C107-C120

[107] Schomberg, H.H., Steiner J.L., Unger, P.W. 1994. Decomposition and Nitrogen Dynamics of Crop residues: Residue Quality and Water effects. Soil Sci.Soc.Am.J. 58:372-381.

[108] Douglas CL, Allmaras RR, Rassmussen PE, Ramig RE, Roager NC. 1980. Wheat straw decomposition and placement effects on decomposition in dryland agriculture of the Pacific Northwest. Soil Sci.Soc.Am.J. 44:833-837.

[109] Funakawa S., Yanai J., Takata Yu., Karbozova-Saljnikov E., and Kosaki T. 2007. Dynamics of water and soil organic matter under grain farming in Northern Kazakhstan - Toward sustainable land use both from the agronomic and environmental viewpoints. In Lal R., et al., (ed.) Climate Change and Terrestrial Carbon Sequestration in Central Asia. The Netherlands. Taylor\&Francis, pp. 279-331.

[110] Six, J. and Jastrow J.D. 2002. Organic Matter Turnover. In Lal R. (ed.) Encyclopedia of Soil Science. Dekker, NY, pp.936-942. 